\title{
The transition to farming and the 'revolution' of symbols in the Balkans. From ornament to entoptic and external symbolic storage
}

\author{
Mihael Budja \\ Department of Archaeology, University of Ljubljana, SI \\ miha.budja@uni-lj.si
}

\begin{abstract}
In desimplifying the logic of colonisation and transition to farming we discuss huntergatherers' and farmer's symbolic structures in the Balkans and Carpathians. Particular attention is paid to the concepts of 'revolution of symbols', 'external symbolic storage' and 'signs of all time'. Our basic premises are (1) that ceramic technology and the principles of fragmentation and accumulation were not the exclusive domains offarmers and, (2) that the hunter-gatherers' symbolic structures and the process of transition to farming were not exclusive and competitive but rather correlative in maintaining control and power within society and over the frameworks of external interactions and exchange networks.
\end{abstract}

IZVLEČEK - V razpravi analiziramo 'kognitivne' pristope in koncepte, povezane s simbolnimi strukturami lovcev in nabiralcev ter poljedelcev. Opozarjamo na interpretativni pomen 'entoptov', 'revolucije simbolov' in 'eksternega hranjenja simbolov' v kontekstu procesa neolitizacije Balkana in Karpatov.

KEY WORDS - Palaeolithic; Neolithic; Eurasia; transition to farming; symbolism

\section{INTRODUCTION}

The prejudices toward hunter-gatherers in general, and Mesolithic peoples in particular, are well embedded in the context of the humanistic evaluation of the genesis of European civilization ever since historian Herodotus of Halicarnassus (ca 485-425 BC) marked the agricultural frontier in his book The History as the boundary between the civilized and the barbarian worlds. The prejudices became broadly accepted in the typologically oriented perception of European prehistory as Gordon Childe put forward the concepts of 'an oriental view' and of the European Neolithic 'as a story of imitation' and 'at best, an adaptation of Middle Eastern achievements' (Müller 1972.101-131; Trigger 1980.66-67; Budja 1996. 61-76).

It was suggested that changes in collective psychology - 'the revolution of symbols'- must have prece- ded and engendered all the others in the process of transition to farming, and that the regions peripheral to the Levant did not become neolithicised until the new ideology reached them (Cauvin 2000.23, 207-208). Steven Mithen, thinks on contrary, that the rise of agriculture was a direct consequence of 'an integration of technical and natural history intelligence' evolved with the emergence of 'cognitive fluidity' (a term denoting how the modular human mind has learned to work) and the origins of art, religion, and science in the upper Palaeolithic. There were domestications of plants and animals that can only be related to the initial Neolithic (Mithen 1996. 217-226).

In southeastern Europe, the transition to farming has been related to intrusive agricultural communities that created the Neolithic diaspora in which far- 
ming communities dispersed across the regions. It was hypothesised that the migrating farmers brought in the new technologies, symbolic behaviours and symbols. The appearance of pottery has been understood for decades as the exclusive marker of cultural discontinuity between Late Mesolithic and Early Neolithic cultures. Pottery decoration was chosen as the marker of "indisputable typological similarities" with the cultural traditions of Asia Minor on the one hand, and the marker of the Early Neolithic ethnic groups on the other.

In the scenario of endemic movement, 'earplugs' 'pins' and 'stamp seals' are hypothesised to have been well embedded in the baggage of the immigrants. They have been understood as signifiers of a 'marine version of the wave of advance model' (Renfrew 1987.169-170), and also used as markers of the Near Eastern 'great exodus' and 'insular colonisation' of the Balkans (Perles 2001.283-290; 2003. 99-113).

It was hypothesised also that social and symbolic domestication preceded the transition to agriculture in the northern Balkans (Hodder 1990.31-32, 41-43).

In desimplifying the logic of colonization and transition to farming in southeastern Europe we pointed out elsewhere that elements of the Neolithic package are well embedded in hunter-gatherer social contexts and that Neolithic symbolic structures in the Balkans do not mirror the paradigmatic ornamental and symbolic principles of Asia Minor (Budja 2003a; 2003b; 2004 in press)

\section{IN PURSUIT OF THE SYMBOLIC}

The dichotomy between the material world and invisible ideas and feelings are topics under constant discussion. It may appear trivial, but while anthropologists can usually assess the functions and meanings of most artefacts and symbols by correlating them with selected, observable behaviours, pre-historians must construct hypothetical behaviours which can never be verified directly. Assigning functions to prehistoric artefacts therefore relies exclusively on inferential arguments and the axiomatic principle that artefacts are material containers that convey archaeologically accessible symbolism to the degree that we think they are material and cultural. Discussing 'Symbolic Archaeology' John Robb (1998.331) pointed out an interpretative paradox: "If we understand how a prehistoric rock carvings was made tech-

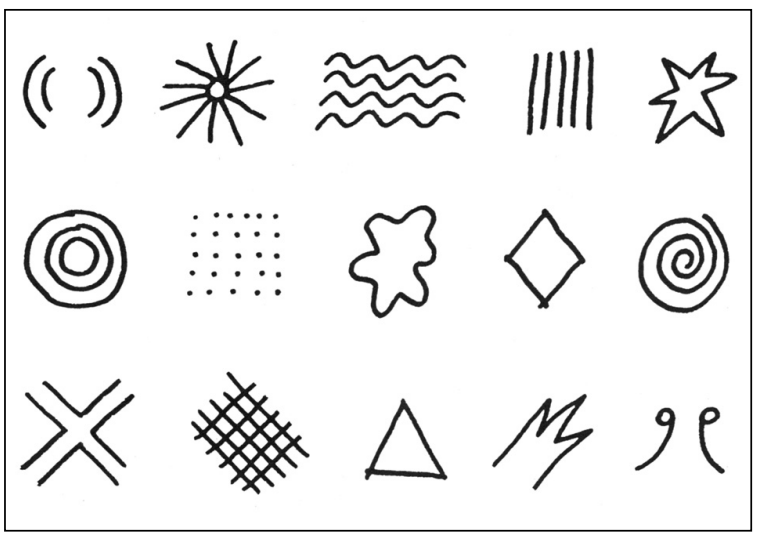

Fig. 1. Entoptic basic categories, each represented here by a typical form (after Oster 1970.87).

nologically without knowing why it was made culturally, the effort is considered a failure, and symbolic archaeology is pronounced impossible. But if we understand how prehistoric people produced their food technology without knowing the cultural reasons why they produced what and how much they did in the way they did, the effort is considered a successful demonstration of economic archaeology; never mind that we have reduced a complex, valueladen set of social relations to a simple faunal inference."

However, at the risk of oversimplification, he outlines three major traditions that archaeologists have followed in conceptualizing symbols: the structuralist, the processual, and the post-modern. Each has its own preferred objects of study, understandings of social relations and power, and epistemology. While the first tradition treats symbols as cultural structures, in the second they have been viewed as tokens that represent reality. In the last, symbols have been manipulated as tesserae, arbitrarily incorporated into phenomenological experience ( $R o b b$ 1998.329-340). In the heuristics of identifying symbols, 'top-down' and 'bottom-up' approaches have been recognized. Ethnographic-cultural narratives have significant positions in both, whether embedded in a cultural matrix within which clusters of archaeological data can be integrated into meaningful virtual behaviours or in reconfigurations of the data within middle-range hypothetical interpretations (Bouissac 2004. online).

What we find to be creative approaches in the archaeology of symbols have been conceptualized as entoptics, 'the signs of all times' (Lewis-Williams and Dowson 1988; 1993), and as the cognitive model of 'external symbolic storage' (Donald 1991; 1997; 1998a; 1998b). 
The syntagm 'external symbolic storage' relates to "...the most salient and indisputable property of material culture: it exists only in relation to interpretative codes stored inside the heads of the people who invented it, that is, inside their 'biological' memory systems. Written symbols, and even other less explicitly symbolic aspects of material culture, are external to biological memory, and serve as storage devices for the information needed to replicate entire cultures. This simple fact changes the nature of shared cognition. But it also makes the archaeologist's job very difficult, because the specific content of symbols can never exhaust their functions when in use. When in use, symbols engage biological memory, which is creative, constructive, dynamic, force. Symbols and cognitive artefacts are thus drawn into a maelstrom of shared cognitive activity in any culture. Artefacts are static things, and undoubtedly serve as static storage devices, but their functions in the larger cultural matrix go well beyond mere storage, because they are in dynamic interaction with the entire cognitive-cultural system in any living culture." (Donald 1998b.184). Donald recognized external symbols as very powerful transforming forces in human life that altered the cognitive landscape as they became more potent storage devices, capable of storing explicit and more detailed knowledge.

Donald's model proposes three stages/transitions in the evolution of culture and cognition. The first and the second cognitive transformations are still genetically based and linked to the development of mimetic skills and lexical inventions related to oralmythic culture. The third, the transition from preliterate to symbolically literate societies, relates to the externalization of memory storage which rapidly involves new memory media and new types of symbolic artefacts. It began in the Upper Palaeolithic, and has been marked by a long and culturally cumu-

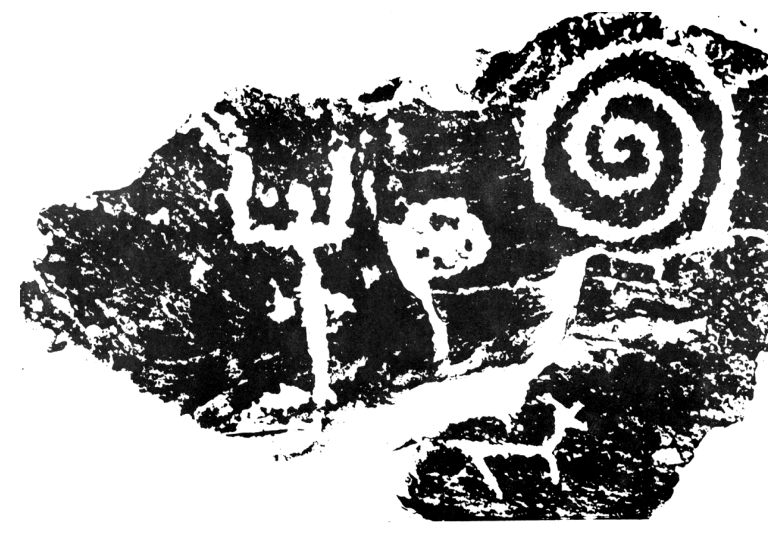

Fig. 2. Petroglyph in Helan Mountains, China (after Xu Cheng and Wei Zhong 1993.353). lative history of 'visuo-symbolic' invention, which advanced through various well-documented stages, culminating in a variety of complex graphic and numerical conventions, and writing systems. External memory evolved to the point where records, mediated by a "literate" class, started to play a governing role and a variety of large, externally-nested cultural products, called theories, emerged.

In the process of the externalization of memory, he conceptualized four structural arrangements. We point out two of these: cognitive reorganization and the changed role of biological memory (Donald 1997.744-747).

The first introduced new cognitive skill-clusters that are referred to as 'literacy' routines, including full symbolic literacy extends, which are well beyond the traditional Western perception of literacy, that is, alphabetic reading competence. The neuropsychology of various acquired dyslexias, dysgraphias and acalculias has revealed a cluster of functionally dissociable cognitive "modules" in the brain that are necessary to support these skills. It is hypothesized (see above) that 'literacy support networks' are anatomically and functionally distinct from those that support oral-linguistic skills. There are three dissociable, visual, interpretative paths involved in symbolic literacy: the pictorial, ideographic, and phonetic. They emerged at different historical phases of visuo-symbolic evolution, and remain functionally independent of one another. The most basic is pictorial, and is needed to interpret pictorial symbols such as pictograms and visual metaphors. The second, ideographic, maps visual symbols directly onto ideas, as in the case of Chinese ideographic writing, most systems of counting, and analogue graphic devices like maps and histograms. The third is phonetic, and serves to map graphemes onto phonemes, as in alphabetical print.

The second structural arrangement, the changed role of biological memory, relates to the way in which external mnemonic devices alter human working memory. Working memory is generally conceived of as a system centred on consciousness. Using a cognitive system model, Donald hypothesised that when we think, we either imagine, via the sketchpad (responsible for the manipulation and temporary storage of visual and spatial information), or verbalize, via an articulatory loop (responsible for storing speech-based information). In preliterate cultures, all individuals have had to work with this, and its limitations are well documented. 
This situation changed with the increased use of external symbolic storage and the breaking out of this limited working memory arrangement. The larger architecture within which the individual mind works has changed - the structure of internal memory is now reflected in an external mnemonic context that serves as the real 'working memory' for many mental operations, and as an external 'long-term' store. It allowed for important new developments, new meta-linguistic skills, the kinds of symbolic products and cognitive

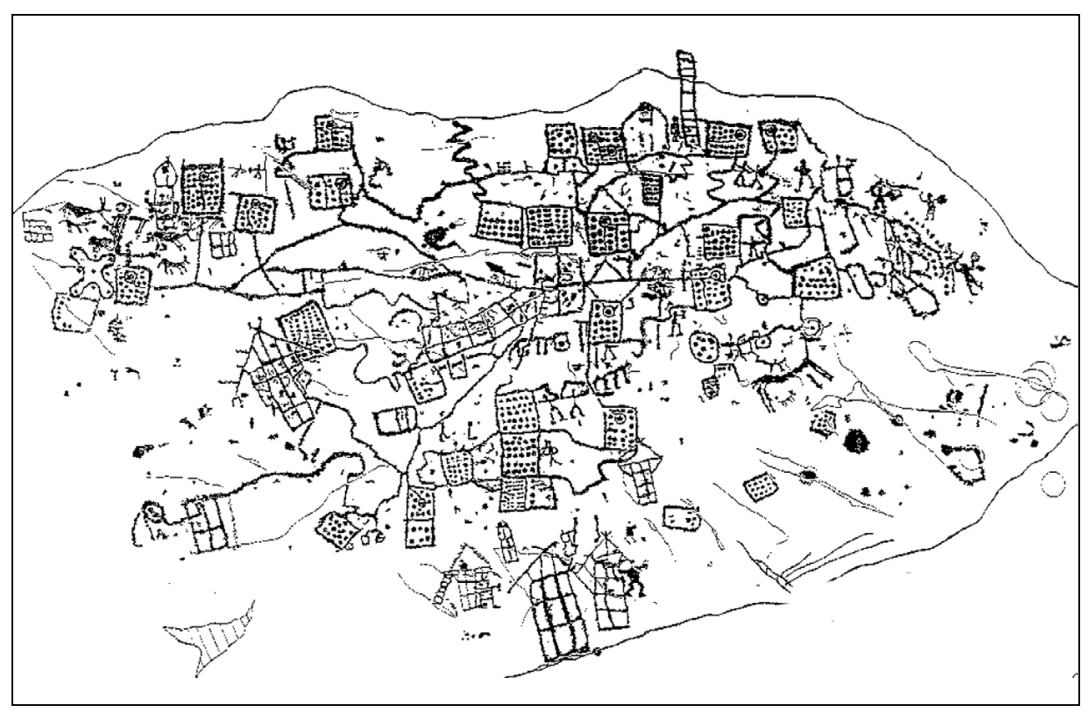
artefacts that humans could produce and maintain. It is believed that any single new entry in the external storage "system, from Palaeolithic cave-paintings to modern science, has never been a trivial occupation" (Donald 1997.737-791; 1998a. 7-17).

This model has been criticised because of its inconsistent correlation of the sequence of evolution of material culture and the sequence of cognitive transitions. Renfrew (1998.3-4) disagrees that the (third) transition to "theoretic culture utilizing external symbolic storage' is marked as a palimpsest of a long and culturally cumulative history from upper Palaeolithic paintings to early writing systems in Mesopotamia. External symbolic storage employing symbolic material culture, he suggests, was not a characteristic of hunter-gatherer, but of agrarian societies, and the third transition can be equated only with the transition to farming. External symbolic storage in the form of writing, he adds, is a marker of a fourth transition and urban societies.

Parallel to 'external symbolic storage' Lewis-Williams and Dowson (1988.201-244; 1991.149-162; 1993.55-65) proposed the concept of 'the signs of all times'. The proposition is based on a neuropsychological bridge between modern experiences in altered states of consciousness and Palaeolithic and Neolithic imagery. They actualize the idea, originally proposed by Oster (1970) in America and Eichmeier, Höfer, Knoll and Meire-Knoll (Eichmeier and Höfer 1974) in Europe that the abstract ornaments and motifs on Neolithic pottery, clay stamps, megalithic art, rock paintings and engravings in Europe, Africa and Australia derived from the luminous, geometric entoptic phenomena, known also as form constants

and phosphenes, seen in certain altered states of consciousness.

Neuropsychological laboratory experiments have shown that in an initial stage of trance, participants see luminous, pulsating, enlarging, fragmenting and changing geometric forms which include grids, sets of zigzags and parallel lines, dots, triangles, squares, circles, spirals, arcs, crosses, meanders, and nested centenary curves. (Fig. 1) These forms are defined as entoptic phenomena because they are 'within the optic system' and are independent of an external source of light. In the deeper, second stage of trance, participants try to make sense of these forms by elaborating them into iconic forms as objects familiar and/or important to them. In religious contexts they become important ritual objects. In the third and deepest stage of trance, mental imagery is more culturally controlled, and entoptics tend to be peripheral. The participant's attention is focused on iconic hallucinations of animals, people, monsters and highly emotional events in which they themselves participate. At this point of visual hallucination two intertwined principles overlap: geometric, entoptic images that derive from the universal human nervous system (neurologically controlled elements), and culturally controlled iconic hallucinatory visions of culturally controlled items such as animals and people, as well as somatic and aural experiences that derive from the subject's mind or culture (psychological elements). The complex iconic images appear to drive from memory, and are often associated with powerful emotional experiences. This shift to iconic imagery is also accompanied by an increase in vividness. Both kinds of image are processed or transformed according to neurologi- 


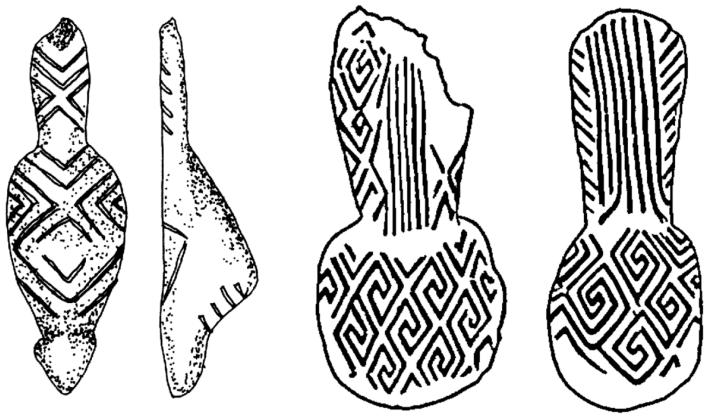

Fig. 4. Upper Palaeolithic ivory figurines. Mezin, Desna River basin, Ukraine (after Abramova 1962. XXXI).

cally based principles such as replication, fragmentation, combination, rotation, superpositioning, and juxtapositioning. The ways in which subjects perceive both entoptics and iconic hallucinations are many and varied. In such an experience a grid or dots may be integrated with animals and people, or an animal can be blended with the characteristics of another species and combined to produce composite animals and therianthropes. These three stages are not necessarily sequential, but cumulative.

Lewis-Williams and Dowson applied the three stage model of altered consciousness to two known and ethnographically well documented shamanistic arts from different continents and to Upper Palaeolithic paintings and engravings, both mobile and parietal, as well as to Neolithic megalithic art. The first is that of the southern African San (Bushman) rock paintings and engravings. The second is Shoshone Coso rock art of the California Great Basin. Both arts are known historically and ethnographically to be shamanistic. San rock art was favoured because shamanistic images can be studied simultaneously from two directions: neuropsychological approach explains the forms of depictions; the meanings of these depictions can be established from directly relevant ethnography.

In applying the neuropsychological, three stage model of altered consciousness and its utility to Palaeolithic and Neolithic imagery, they say that as many as 437 of the 488 (or $90 \%$ ) societies that have been surveyed had some form of institutional altered states of consciousness. They ranged from foraging to more complex societies and, therefore "there are a priori grounds for suspecting some form of institutionalised altered states during the Neolithic" (LewisWilliams and Dowson 1993.55; see also Sherrat 1991.50-64). However, as neuropsychological research has shown that hallucinations comprise geometric and realistic imagery, we have to be cautious in claiming that Upper Palaeolithic or Neolithic art derived "in part from the mental imagery of altered states if only signs had been present", and that "practically any geometric motif by itself" can not be recognized as entoptic in origin and therefore indicative of shamanism (Lewis-Williams and Dowson 1990.407; Lewis-Williams 2004.107).

It is hypothesised that at "least some Palaeolithic people experienced hallucinations induced by one or more of the many techniques that range from the ingestion of psychotropic drugs to sensory deprivation", and their mental imagery "would necessarily have included hallucinations very like the range of depictions in their art" (Lewis-Williams 1991.158; 2002). It has also been shown that altered states of consciousness can be experienced in a variety of circumstances other than shamanism, and that entopic phenomena can be seen in migraine attacks and schizophrenic conditions (Asaad and Shapiro 1986.1088-1097; Richards 1971.88-96). However, migraine-induced visions have certainly have played a role in religious experience in the European Christian tradition and, there is no need to exclude the variety of mental disorders, including schizophrenia, migraine and epilepsy, as well as the induction of altered states of consciousness by sensory deprivation, rhythmic dancing, hyperventilation, and pricking sensations etc. (Eliade 1972; Pearson 2002).

Sherratt (1991.51-52, 54, 61-62) indicates the importance of sensory-altering substances by saying that there would have been an extensive knowledge of the 'various mood-altering substances' which were available in the natural flora, and which survive today in the attenuated form of 'herbal reme-
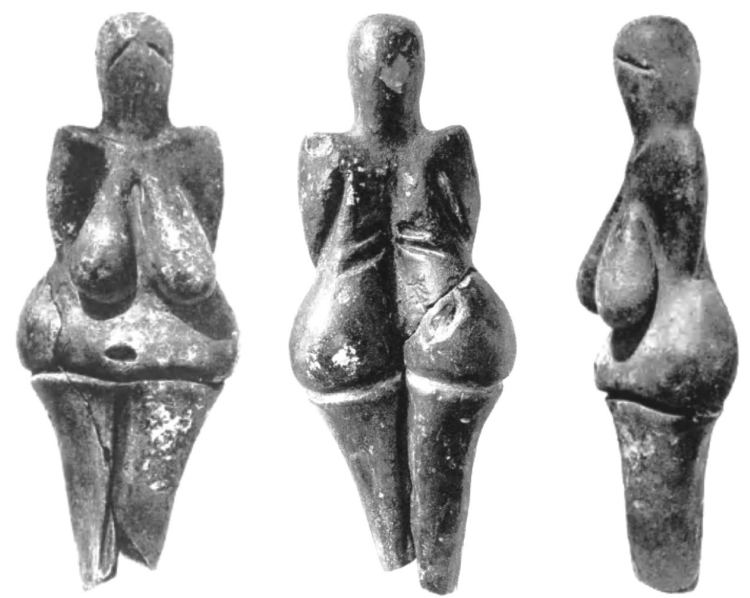

Fig. 5. Ceramic 'Black Venus' of Dolní Věstonice (after Soffer et al. 1993.Fig.1) 
dies'. The quantity of the stimulant need not be large, as it may be enhanced by fasting or breath control. Such experiences are likely to be deliberately sought in the course of ceremonies or rituals, at that time perhaps seen as a means of accessing other worlds. He sums up by saying that there was a considerable potential for the spread of even mild stimulants and of methods of preparation which enhanced their effectiveness and, that "any account of prehistoric Europe which omits a consideration of such substances is likely to be incomplete". Along the written records which give many accounts of drug use he notes some concrete evidence - ceramic pots for smoke inhalation in the Mihailovka, Tripolye, and Bodrogkeresztur cultures in eastern Europe, and in megalithic complexes in western Europe.

It is reasonable, therefore, to assume that some form of shamanism can be applied to early prehistoric art to objectify a religion centred on altered states of consciousness. Because the human nervous system is everywhere alike, we can assume that the effects of its functioning were the same from the Aurignacien to the present, and in all parts of the world. Neuropsychological research has shown that visual hallucinations experienced in altered states are cross-culturally uniform (Eichmeier and Höfer 1974; Lewis-Williams 1991.159-160; 2002.189227; Dowson 1998a. 73; 1998b.333-343; Dowson and Porr 2001.165-177).

However, what needs to be mentioned is a criticism of the thesis that archaeological findings may be interpreted as shamanic and that there exists something like a 'general shamanic ability'. Anthropologists have made a coherent and strong front against, as they want to be "a refreshing antidote to a regrettable phenomenon...i.e. the uncritical and unfounded presentation of 'shamanism' as a key to understanding prehistoric rock art." (Francfort and Hamayon, Bahn 2001.51). The concept of 'the signs of all times' has been ideologised, such that rock engravings should be understood as homogenous religious phenomenon shared by the 'primitives' of all times and places, from Eurasian Palaeolithic hunters to the San of Africa and Shoshone of America, having one religion and one iconography, while 'high' civilizations have complex religious and religious iconographies. It is believed, paradoxically, that archaeologists marginalized shamanic processes to the level where rock art is interpreted as the creation of shamans, who, after a trance experience induced by obsessive dancing, fasting or hallucinogenic drugs, depict their visions on rocks and artefacts

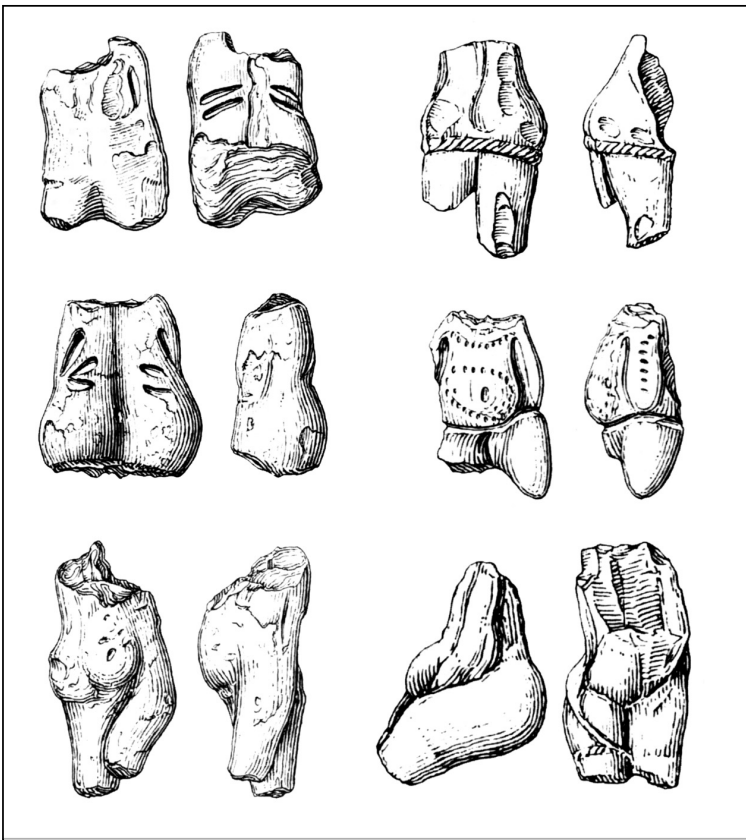

Fig. 6. 'Fragmented' anthropomorphic ceramic figurines from Dolní Věstonice and Pavlov (after Verpoorte 2001.Figs. 3. 6, 7, 8, 9, 46 and 54).

(Layton 2000.169-186; Klein et al. 2002.383-420; Helventson and Bahn 2003.213-224; se also Hodgson 2000.866-873).

We will not enter into a discussion of the diagnostic element of shamanism and the social status of shamans, but point out the concept of 'labelled landscape' that one may find neutral. That is to say, preand historically interactive symbolic palimpsests are available where replicated, fragmented, combined, rotated and superpositioned entoptics associated with animals and people have been recognized as evidence of an external symbolic storage of spatial knowledge, not necessarily related to a shamanistic interpretative network.

\section{LABELLED LANDSCAPE}

Along with temporal continuity, geographical continuity - the universal occurrence of rock art in Eurasia, Africa and Australia - has been demonstrated elsewhere. The rock art of China seems to be the earliest that has been recorded in historical documents, as early $6^{\text {th }}$ century $\mathrm{AD}$, when the geographer Li Daoyuan (472-527) mentioned the rock engraving in Shuijing Zhu (Commentary on the Classic of Rivers), he saw while surveying the land in many parts of China (Chen Zhaofu 1991.26-36).

The Chinese rock art concentrations, found along the northern frontier close to the remains of the 


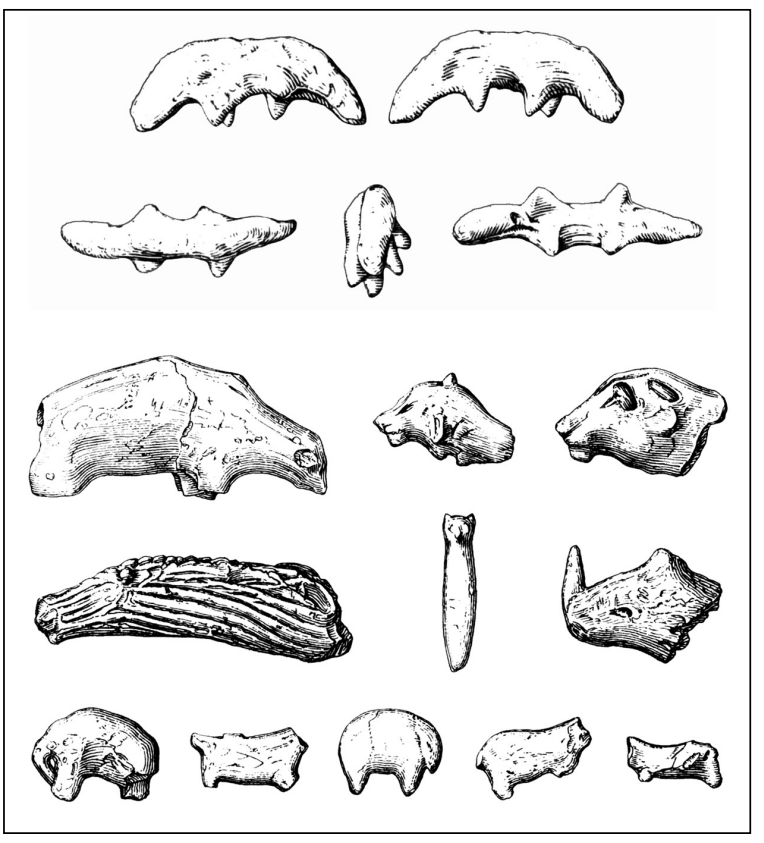

Fig. 7. Zoomorphic ceramic statuettes from Predmosti and Dolní Věstonice (after Verpoorte 2001. Figs. 3.73 and 8.1).

Great Wall, apparent symbols of the Chinese empire, have been studied recently (Xu and Wei 1993; Demattè 2004.5-23) (Fig. 2). Petroglyph sites are located on the two main mountain ranges: the Yinshan of Inner Mongolia, which runs for over thousand kilometres along the Yellow River, and the Helanshan of Ningxia Province. Archaeological and historical data indicate that for millennia - from the Neolithic to the later dynastic phases in the nineteenth century - these areas were (military) borders that separated different economic lifestyles, nomadic pastoralism in the north and arable farming in the south. It is believed that these mountains were chosen as petroglyph sites not only because they provided stone surfaces necessary for carving, but also because their canyons were on communication routes which connected the world of the steppe with China. Archaeological and textual evidence shows that the northern silk route passed through these areas, and that the local nomadic populations were engaged continually in exchange and trading activities. Paola Demattè suggests that the petroglyphs and paintings there were not only associated with religion, ritual and shamanistic activities, but also related to more prosaic activities such as dotting the landscape. It is that nomadic societies created their own signs to mark borders and to reiterate 'the symbolic attachment' to the land with which they identified. She points out a 'deeper and visual connection' between the single petroglyphs and written signs of the earliest (iconographic and symbolic) types (generally known as pictographs). It cannot be overlooked that these pictures also functioned in roles which in literate societies are taken up by writing. If the function of writing and that of petroglyphs may have something in common, there is also a deeper and visual connection between the two, particularly if the single petroglyphs are compared with the earliest pictographic forms of writing. In later periods, when writing became more widespread among the nomads, writing and engravings were combined and sometimes petroglyph production disappeared and writing took over the same surfaces. The inscriptions in Xixia script appended next to earlier petroglyphs describe them as 'the parents of writing' or 'the writing of the spirits of writing', thus making clear the close connection perceived by literate people between the two sign systems (O.c. 20). The systematic simplification and transformation of images into easily recognizable narrative symbols is an acceptable indication that petroglyphs were probably used to record and communicate information, perhaps to later generations, neighbouring groups, or even encroaching enemies. Similar spatial communication 'is also not unlike' that of literate cultures which were attached to their social territories by writings, edicts, historical inscriptions etc. (Demattè 2004.17-21). A similar 'borderland' concept has been applied recently in the interpretation of rock art distribution in Europe (Bradley 2000; see also Coles 2000).

There is no doubt that signs, labelling the landscape at significant locations, have been embedded in multiple functions and levels of symbolic behaviour, including spatial perspective. But more indicative are the alternative contexts where the topographic maps and complex landscape representations have been attached to rocks, house walls, and pots. There is a

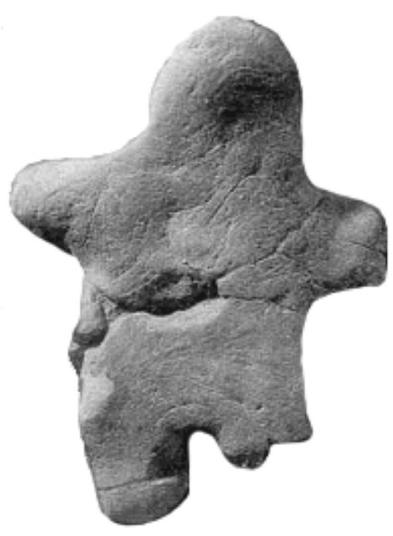

Fig. 8. Anthropomorphic ceramic figurine from Maina, Yenisei River basin in Siberia (from Vasil'ev 1985.Fig.2). corpus of 43 prehistoric maps available, ranging from Almaden Upper Palaeolithic cave painting to Iron Age rock carving in Val Camonica, and a list of 67 hunting, fishing and gathering societies that created such maps (Zubrow and Daly 1998.164165, 170). Palaeolithic and Neolithic petroglyphs, cave paintings, rock paintings, wall paintings, and 
bone engravings are pictorial, including all the the signs of all times'. They are considered to be maps, as they display spatial relationships. They tend to have a focal point, in that emphasis and resolution decrease with distance from familiar points; and they show usage, ownership and horizon marking (O.c. 167). The well-known examples are the petroglyphic maps at Bedolina in Val Camonica in the Dolomites (Turconi 1998.85-113) (Fig. 3), a wall painting map in Çatalhüyük (Mellaart 1967.Figs. 59, 60) and the famous Tepe Gawra landscape jar ( $c f . Z u b$ row and Daly 1998.Figs. 13.1-2). All the items listed have been hypothesised as memory devices and, we may additionally say they are multifunctional and multidimensional in symbolic behaviour. The palimpsests of 'entoptics', 'pictorial' and 'ideographic' visual representation are still driven by mimetic organizational principles, although they operate as external symbolic storages at a different, more sophisticated level. However, they clearly reflect the external representation of spatial knowledge.

\section{THE GREAT GODDESS OR DRESSED CERAMIC VENUS, SHAMANISM, EXTERNAL SYMBOLIC STORAGE, AND THE ORIGINS OF CERAMIC FRAGMENTATION}

The small series of early Upper Palaeolithic sculptures in Europe consisting of female figurines, therianthropes, and several animal figurines is believed to have been followed in Gravettian by numerous zoomorphic and anthropomorphic figurines carved from mammoth ivory, bones and tusks, limestone and marble, or modelled in ceramics. There are corpuses of some 200 female figurines, and a much larger, but ill-defined number of animal figurines whose distribution in Eurasia from the Pyrenees to Lake Baikal in Siberia indicate a Gravettian cultural tradi- tion. The main focus of attention has been on Palaeolithic depictions of women, commonly named Venuses. Less attention has been paid to stylized female figurines and the 'design motifs' attached to them. This selective focus on the emotionally charged primary and secondary sexual characteristics has led to 'gynecocentric' (see Meskell 1995.74-86) explanations of symbols of fertility, palaeo-erotica and selfportraiture on one hand, and conflicting conceptualizations of female divinity and the nature of mother goddesses (Ucko 1968; Gamble 1982; Gimbutas 1982; 1989; 1991; Marshack 1991.17- 31; McDermott 1996.227-275; Goodison and Morris 1998; Soffer, Adovasio and Hyland 2000. 511- 537).

It is worth remembering that Marija Gimbutas, although finding the model of the 'Great Mother' deity inconsistent with her conceptualization of the complex of nineteen female divinities embedded in the 'Great Goddess' (1989), applied to the Palaeolithic parthenon the 'bird goddess' only. She believes she has identified and decoded at least fifty ideograms, including many geometrical and other 'abstract signs' and 'animal symbols', but there is, again, a very limited number to which she applied to Palaeolithic imagery, and all of them supposedly relate to 'aquatic symbols', 'waters of life' and 'aquatic family' (Gimbutas 1982; 1989).

Three-dimensional imagery, animal statuettes, human figurines and therianthropes, (whether they bear geometric signs and entoptics or not), have been hypothesised in an alternative approach as shaman's helpers - it is believed they were reified spirit animals and dead ancestors, with all their prophylactic and other powers, as integral parts of shamanism (Lewis-Williams 2002.169-293; Schlesier 2001.410; see also Layton 2000.169-186). The suggested examples from Europe (Předmostí, Dolní Věs-

\begin{tabular}{|l|c|l|l|}
\hline Site & Anthropomorphic & Figurative & 'Ceramics' \\
\hline Dolní Věstonice I & 12 (note 1) & $>721$ & $>5,760$ \\
Dolní Věstonice II - north & - & $\geqslant 2(10 ?)$ & 431 \\
Dolní Věstonice II - west & - & 1 & 7 \\
Dolní Věstonice III & - & - & $1 ?$ \\
Pavlov I & 8 (note 1) & $>100$ & $\sim 10,000$ \\
Pavlov II & - & $?$ & $\sim 135$ \\
Předmostí I & - & $\geqslant 2$ & $>2$ \\
Jarošov II & - & - & $1 ?$ \\
Krems-Wachtberg (note 2) & - & 3 & 3 \\
\hline
\end{tabular}

Fig. 9. Ceramic assemblages of Upper Palaeolithic Pavlovian sites in Central Europe (after Verpoorte 2001.Tab. 5.1). 


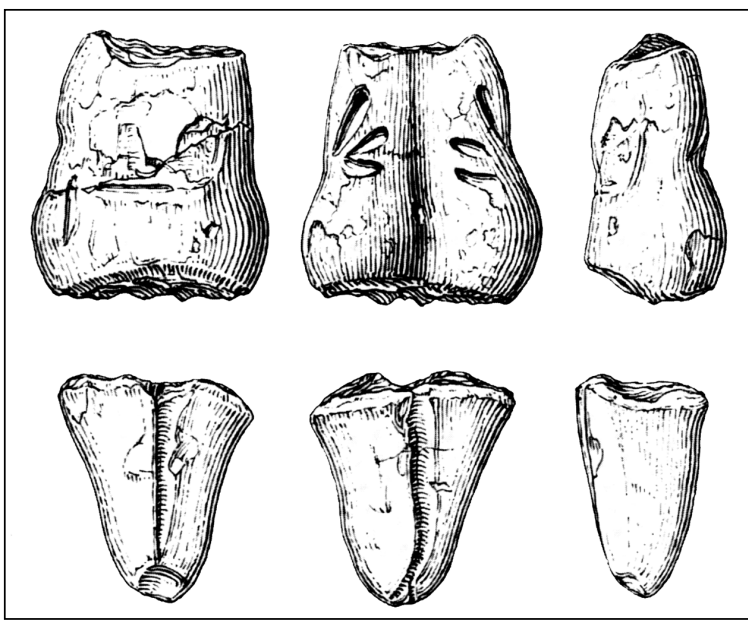

Fig. 10. Composed ceramic figurine, Dolní Věstonice in Moravia (after Verpoorte 2001.Fig. 3.6).

tonice) and Siberia (Mal'ta) are embedded in Gravettian and Solutrèan cultural contexts.

A much more simplistic approach focuses on the question of whether Gravettian Venuses in Eurasia depict an Upper Palaeolithic ideology of dressing or not. The results of very recent studies indicate 'dressed female bodies' and the occurrence of textile use and weaving technology. The focus has thus been moved from the sexual characteristics to 'symbols of achievements' of female weavers and related power, prestige, and value (Soffer, Adovasio and Hyland 2000.511-537; Soffer and Adovasio 2004.270282). The 'geometrical design' on Mezin's figurines have been recognized as weaving patterns and design elements that can be linked to 'East European Slavs' (2000.533) (Fig. 4). We agree, they can be interpreted as aniconic geometrical designs for all times, but they might also have been acting as entoptic phenomena.

Despite the strong wind of interpretative change, there are still some intriguing points in interpreting Upper Palaeolithic imagery and technologies. Janusz K. Kozłowski has pointed out recently that "Gravettian Venus figurines exhibit more characteristics in common with the figurines of the initial Neolithic of the Near East than with the Late Magdalenian or Epigravettian". His comment was marginalized, as it revives Gimbutas interpretation, and conflates time and space (Soffer, Adovasio and Hyland 2000.526, 533; Koztowski 1992).
However, it is broadly accepted that there are many thousands of ceramic artefacts - anthropomorphic and zoomorphic figurines and pellets - across Eurasia, from the Pyrenees to the Yenisei Basin in Siberia, well-embedded in Upper Palaeolithic contexts. We can not avoid the similarities of shape and ornamentation to much later Neolithic figurines in Anatolia and Europe, although thousands of years lie between them, and they appear indifferent social and economic contexts. It is a fact, however, that ceramics were used for figurines, instead of pots and polished stone, for decorative elements instead of axes.

The anthropomorphic figurines, zoomorphic statuettes and pellets of fired clay were produced at Upper Palaeolithic sites at Dolní Věstonice, Pavlov, Petřkovice and Předmostí in Moravia (Klíma 1989. 81-90; Vandiver et al. 1989.1002-1008; Soffer et al. 1993.259-275; Gamble 1999.402-404). The most easterly anthropomorphic ceramic figurine was found at an open air site at Mayininskaya near Maina, on the left bank of Yenisei River in Siberia (Vasil'ev 1985.193-196; Maina online). (Figs. 5, 6, $7,8)$

In Central Europe, ill-defined types of ceramic fragments were found at Krems-Wachtberg, MoravanyLopata, Jarošov, and hypothetically at Kašov and Cejkov (Verpoorte 2001.95-96). On the Russian Plain at Kostenki, on the banks of the River Don, more than four hundred fragments of low-temperature-fired ceramic were found, contextually associated with hearth, marl and ivory Venus figures, and animal statuettes (Abramova 1962; Soffer et al. 2000.814).

At the Dolní Věstonice and Pavlov camps, located about three hundred meters from each other, more than 16000 ceramic objects have been found. According to the available statistics, at Dolní Věstonice almost all the figurines and statuettes are fragmented

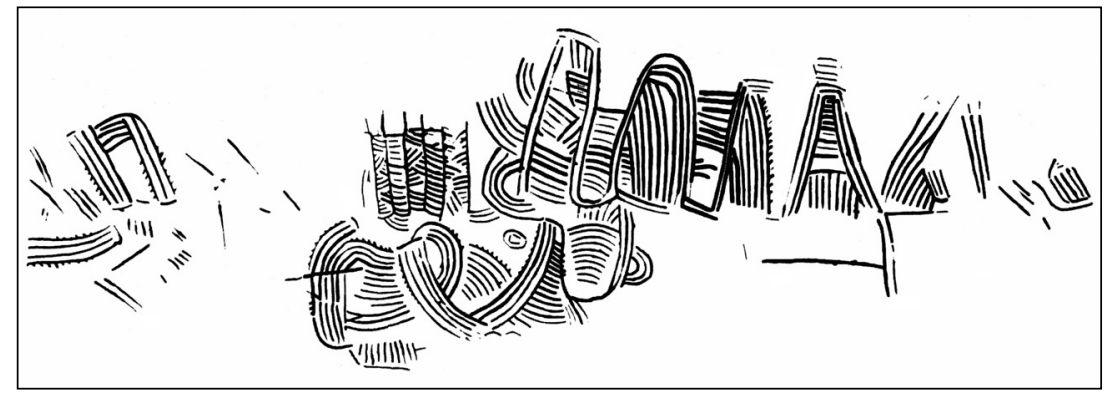

Fig. 11. Entoptic phenomena engraved on mammoth tusk, Pavlov in Moravia (after Verpoorte 2001.Fig. 3.69) 
(Fig. 9). It is interesting to note that, with the exception of Předmostí, ceramic objects at the other sites were contextual associated with hearts or kilns, and that many fractures were not caused by mechanical means, but are high-energy fractures, caused by thermal shock. It should be noted that the pellets and balls which form a large part of the ceramic inventory remained mostly unbroken. This led Vandiver and Soffer to reconstruct the entire process of ceramic production by examining the technological skills which were involved. They found out that the local loess was suitable for shaping the fe-

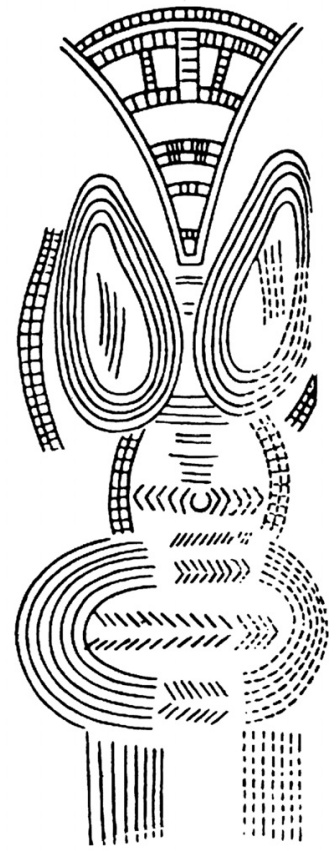

Fig. 12. 'Therianthrope' incised on mammoth tusk, Předmostí in Moravia (after Marshack 1991.Fig.5) male figurines, animal statuettes and pellets. Figurines and statuettes were made of several small pieces of clay stuck together (Fig. 10). Heads, legs, feet, ears and tails were shaped separately and attached to the bodies. They were fired at temperatures between $500^{\circ}$ and $800^{\circ} \mathrm{C}$. The most important finding was the evidence of thermal shock, an explosive reaction which shatters clay when it is being fired. It is believed the figurines, undried or fired at low temperature, had been purposefully rewetted to absorb some liquid, then put into a hot fire where they loudly exploded, sending pieces flying in all directions. It is believed the thermal shock was intentional, and the process of making and firing was therefore more important than achieving a lasting final product. All ivory objects and stone figurines, in contrast, survived in fairly complete states.

We have already mentioned that the majority of ceramics were found in the contexts of everyday activities, but at Dolní Věstonice, around and in the 'oven-like hearth' located in the middle of the hut, "two thousand pieces of 'ceramic', among which about one hundred and seventy-five with traces of modelling" were found (Verpoorte 2002.56, 128). The locus of production located in the settlement may reflect a utilitarian, but controlled behaviour related to making, firing and the noticeable fragmenting of the female figurines and animal statuettes.
We should not overlook the fact that that thousands of clay pellets were not thermally shocked and were quite consistently fired in the higher temperature and equally distributed over the site (Vandiver et al. 1989.1002-1008; Soffer et al. 1993.259275). A much smaller amount of ceramics was found at Dolní Věstonice II, where six modelled fragments had been deposited in the vicinity of a triple burial. Seven more were found in the 'first settlement unit', deposited in "two depressions in the vicinity of a large heart and a male burial" (Verpoorte 2002.95).

Venuses designed for fragmentation are not ornamented. There are a few at Dolní Věstonice and Pavlov bearing almost identical incised pattern on their backs (Soffer et al. 2000.Fig.3; Verpoorte 2001.Figs. 3.6, 3.7, 3.11, 3.79). (Figs. 6, 10) If we accept two basic premises: that the ceramics were not just kiln waste because the makers were 'awfully bad potters' and, that the female figurines and animal statuettes had been intentionally fragmented in well visible and audible explosions, then this was not merely 'playing with fire', but well-controlled pyrotechnic manipulation with newly adopted media - the ceramics. It is worth remembering Gordon Childe, besides the Neolithic revolution, put forward the idea that: "Pot making is perhaps the earliest conscious utilization by man of a chemical change ... this change in the quality of the material must have seemed a sort of magic transubstantiation - the conversion of mud or dust into stone. It may have prompted some philosophical questions as to the meaning of substance and sameness." (Childe 1951. 76-77).

Pot making obviously happened much earlier, and they were not vessels, but female figurines, animal statuettes, and small pellets that appeared in Eurasia first. The figurines from Dolní Věstonice and Pavlov are assigned to the Pavlovian, a local variant of the Eastern Gravettian techno-complex, and dated to

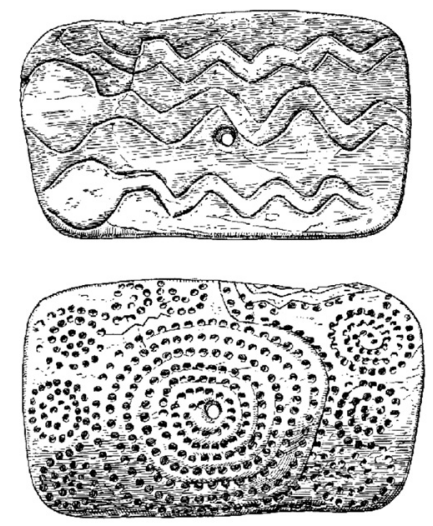

Fig. 13. Entoptics on ivory plate, Mal'ta in Angara River basin, north of Irkutsk in Siberia (Abramova 1962.L. 2, LI. 2). Plate (14.1 $x 8.5 \mathrm{~cm})$ with a drill-hole in its centre features three engraved snake figures on one side and impressed spirals on the other. 

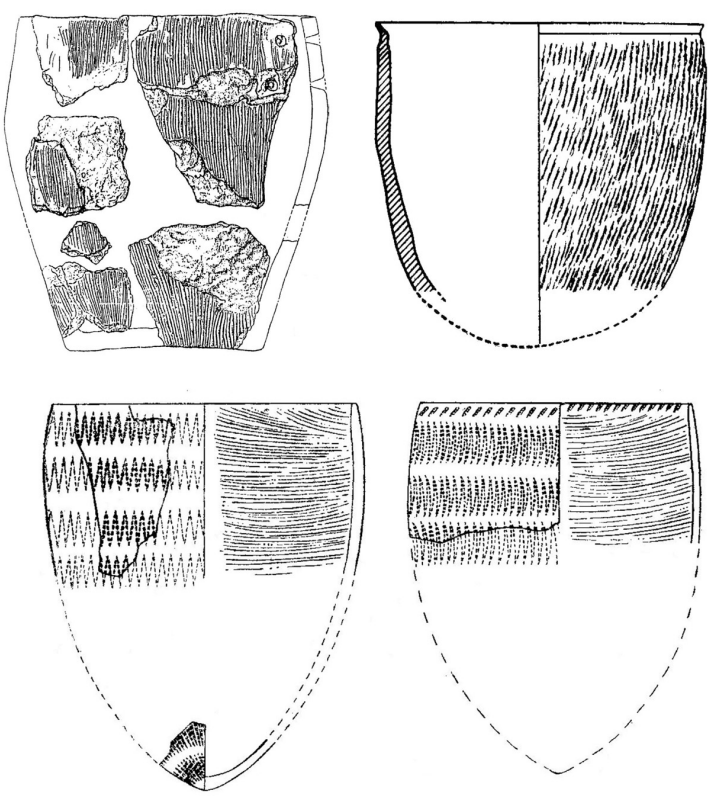

Fig. 14. Pottery in Osipovka and Ust-Karenga cultural complexes in Siberia and Xianrendong site in southern China (after Kuzmin 2002.Figs. 2 and 7; Zhang Chi 2002.Fig. 9).

about 26000 BP (Verpoorte 2001.86). Ceramics at Kostenki are embedded in dates as early as 24100 BP to as late as $18000 \mathrm{BP}$ (Soffer et al. 2000.814). A ceramic figurine at Mayininskaya was deposited in layer 5 , which was dated to $16540 \pm 170 \mathrm{BP}$ and 16 176 \pm 180 BP (Vasil'ev 1985.193-196; 1996; Vasil'ev et all 2002.526, Tab. 1).

It may not be surprising that transubstantiation and fragmentation in the central European Upper Palaeolithic social context, whether formalized or not, were objectified with the help of Venuses, as they represent the principal component of the three-dimensional imagery of Gravettian parthenon. But it is surprising that the entoptics were not attached to new media, although being broadly applied to ivory and bone imagery, and also stone figurines. Did the audio-visual effects of transubstantiation and fragmentation simply replace them, and the visual and audible magic of newly adopted media, which was not conditioned by the shaman's altered states of consciousness, become accessible to the all members of community?

It is believed that ivory and stone Venuses had a much higher value than those modelled in ceramics, as there is no evidence that they were circulating within an alliance or exchange network and that "they were not made to be presented to Palaeolithic spectators" (Verpoorte 2002.99, 108, 129). But it is certainly not the case in Kostenki, where marble, stone and ivory female figurines were broken intentionally, as Abramova (1962.9) pointed out, adding that the number of fragments and traces of repeated pounding might suggest that the destruction of figurines had been ritually necessitated. And we should not overlook engraved entoptic phenomena at Pavlov and therianthrope, an engraved Venus at Předmostí that can be associated with iconic hallucinations. Marshack (1991.24) characterized the latter as 'horned geometric female' and 'mythologized creature'. Ivory plate at Mal'ta with engraved snakes on one side and impressed spirals on the other is believed to objectify a shaman's 'helper' (see above) attached to his costume (Figs. 11, 12, 13).

We mentioned above that we would not enter into a discussion of shamanism and their social status, it is reasonable to hypothesise that ceramic production - manipulation, with transubstantiation as the matter of technical knowledge and skills - may have affected their social position. Bearing in mind the dangers inherent in using ethno-historical evidence, it is worth remembering that in some social contexts and related cosmologies potters may be injurious to others because they cause diseases. The worst thing that could happen was that a rain chief should come into contact with a potter. Both would die. The potter would swell up with moisture, while the rain chief perished from a dry cough (Barley 1994.64).

Is it then possible that ceramic production in hunter-gatherer societies in central Europe was taboo from the end of the Pavlovian? And can we recognize the ceramic artefacts in the Pavlovian cultural context as external symbolic storage involving new technology, media and audio-visual symbolism? If so, we can assume that external symbolic storage employing technical and symbolic culture was therefore a characteristic of hunter-gatherer as much as of agrarian societies (contra Renfrew, see above). But it was not maintained continuously in Europe.

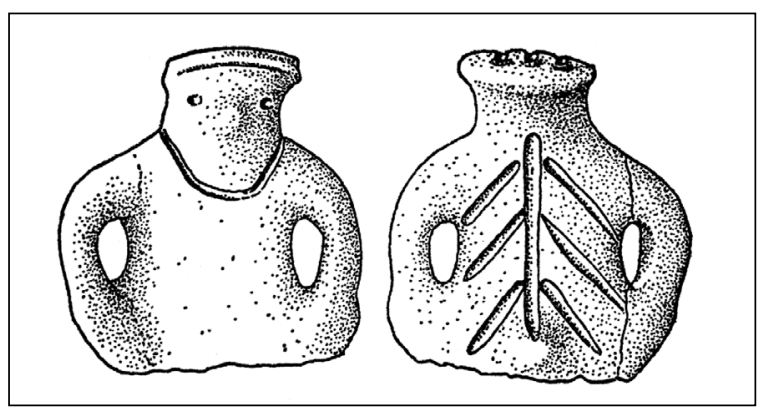

Fig. 15. 'Linearbandkeramik' figurine from Boskovštejn in Moravia (after Höckmann 1967.Abb. 1.1). 
However, it was in Siberia. The chronological discontinuity there is negligible and we might speculate that the knowledge of ceramic technology was maintained continuously as the datating of a ceramic anthropomorphic figurine at Mayininskaya in the Yenisei River basin (see above) is close to that of the

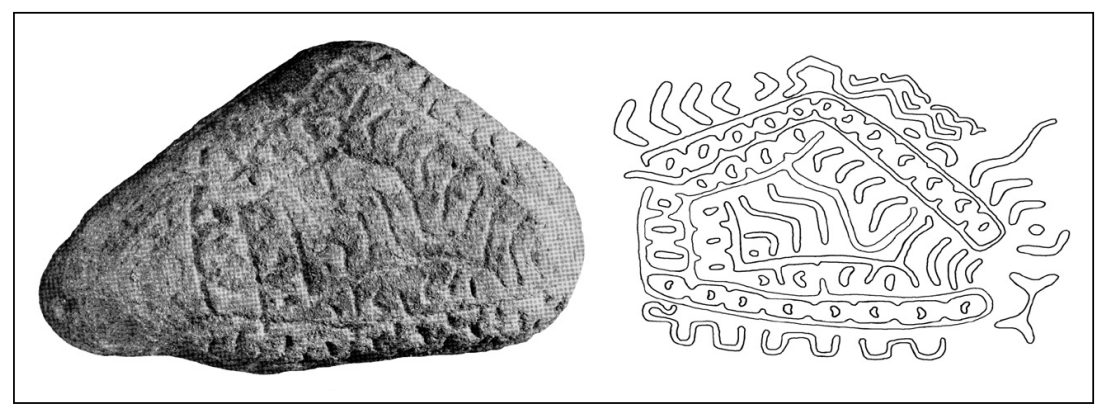

Fig. 16. Lepenski Vir petroglyph (after Srejović and Babović 1983.Fig. 149). earliest pottery that appeared

in the Amur River basin in the settlement contexts of the Osipovka and Gromatukha cultures. Pottery was dated to within the period of ca. 16 500-14 500/ 15 940-14 310 calBP (13 300-10 400 BP) (Kuzmin and Orlova 2000.356-365; Kuzmin 2002.43; Kuzmin and Keally 2001.1125; Kuzmin and Shewkomud 2003.42; Kuzmin et. al. 2003.39-42; Vasil'ev 1985.193-196; 1996; Vasil'ev et al. 2002. 526.Tab. 1).

It has been suggested on the basis of the latest compilation of the earliest radiocarbon dates that pottery was adopted 'almost simultaneously, around 14 000-13 000 BP' in eastern Asia, which evidently predates the transition to farming. The ceramic vessels were thus recorded in cave sites at Miaoyan, Yuchanyan, Xiarendong and Diaotonghuan in southern China; the Odai Yamamoto, Kitahara and Tokumaru Nakata sites of the incipient Jomon (Chojakubo-Mikoshiba cultural complex) in eastern and northern Japan; the Gasya, Khummi, Goncharka and Gromatukha sites in Amur River basin in Siberia. The earliest vessels are described as deep bowls, with flat or pointed bases, with walls up to two centimetre thick. The estimated volume of the pot is approximately 5.5 to 6 litres. The secondary burning, carbonized adhesion, soot and water lines seen on many fragments, suggest that the basic functions of the pottery were boiling water and foods or other organic materials and extracting fish oils from salmonids. There are differences in ornamental motifs between the regions. While in Japan, plain vessels prevail, vertically grooved decoration is typical of Chinese pottery. In Siberia the ornamental principles are more complex, as they consist of vertical and horizontal grooves and zig-zag impressions. On some, the vertical zig-zag 118). designs and horizontal lines were made with a comb, on others, sinuous lines were made by cords (Zhao and Wu 2000.233-239; Zhang 2002.29-35; Kuzmin 2002.42; Keally, Taniguchi and Kuzmin 2003. 3-14) (Fig. 14).

There have been few attempts to explain the principle of fragmentation as a social practice in hunter-gatherer contexts, especially for the ceramics. Departures and arrivals are hypothesised as an obvious motivation for such a rite in forager mobility (Chapman 2000.40-41), and the art (but not diffracted) could have been involved in establishing and maintaining the identity, the genius loci, of these places (Verpoorte 2002.12).

'Fragmented Goddesses' are more intensively discussed in Neolithic farming contexts. It is not because they were believed to posses the special creative magic necessary to coax fertility out of the earth and to be broken and discarded around the village, which brought new life to the soil (Winn 1995), but also because of a wide variety of available ethnographic practices. Figurines are used in initiation rites and then destroyed, buried or kept by an initiate; they are buried with the owners after use in fertility rites; they act as tokens in economic and social transactions (Talaly 1993). The principles of fragmentation and accumulation in the contexts

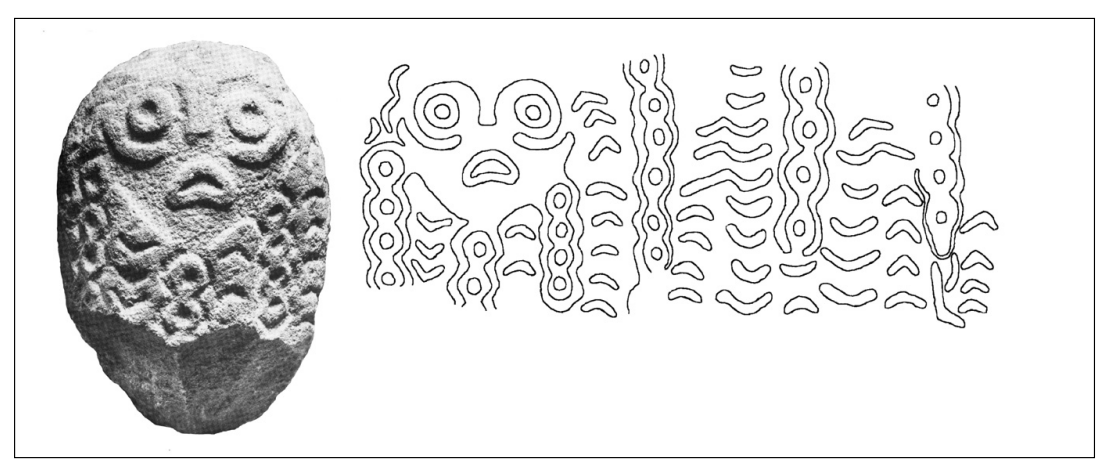

Fig. 17. Lepenski Vir 'therianthrope' (after Srejović and Babović 1983. Fig. 
of social interactions between persons, objects and places (Chapman 2000), and 'diffracted' approaches in studies of predominantly female figurines in 'early villages' (Lesure 2002) have been narrated recently.

For our approach, it is more important that in the Far East, in Jomon huntergatherer contexts, female figurines were incorporated into community rituals, where they were deliberately broken and scattered around the village (cf. Chapman 2000.25-26). Höckmann hypothesised a similar pattern in the central European Linearbandkeramik settlements, where the majo-

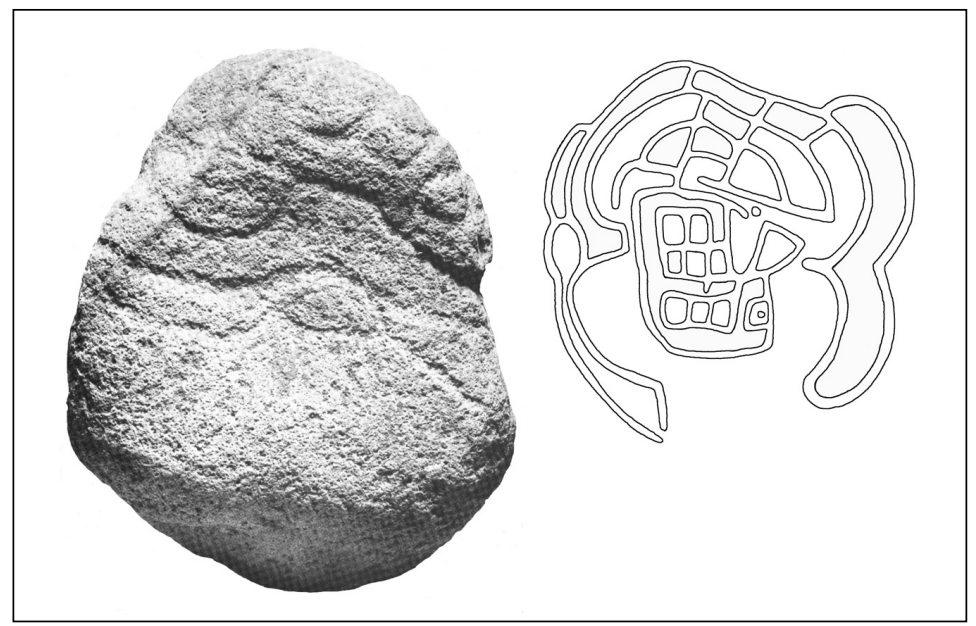

Fig. 18. Lepenski Vir 'topographic map' petroglyph (after Srejović and Babović 1983.Fig. 130). rity of figurines were intentionally broken and deposited as fragments, some still bearing an incised pattern on the backs similar to the Gravettian Venuses at Dolní Věstonice and Pavlov (Höckmann 1967.2, Abb. 1.1, 5.1) (Fig. 15).

One can find of interest the ceramic 'earplug' embedded in a Gravettian assemblage at Pavlovi (Klíma 1989.88, $A b b .4 q$ ). It is well known that earplugs have been played an important role in the scenario of endemic movement and early Neolithic colonization of Europe. Their restricted geographical distribution, as well the distribution of "pins" and "stamp seals", is used as a key argument in modelling "insular colonisation" and rapid displacements over long distances, as they were hypothesised to be well embedded in the baggage of the immigrants. They have maintained this position since Milojčić conceptualized the pre-pottery Neolithic in Greece (Renfrew 1987.169-170; Perles 2001; 2003.99-113; Milojčić 1959(1960).6; 1960.327-328).

\section{BOULDERS, POTS, ORNAMENTS AND/OR ENTOP- TICS IN THE BALKAN MESOLITHIC AND NEO- LITHIC}

We mentioned at the beginning that the transition to farming in southeastern Europe was related to intrusive agricultural communities that created the Neolithic diaspora in which farming communities dispersed across the regions. It was hypothesised that the migrating farmers brought in the new technologies, symbolic behaviours and symbols. The appearance of ceramic technology and pottery production has been understood for decades as the exclusive marker of cultural discontinuity between Late
Mesolithic and Early Neolithic cultures. The white and red painted pottery decorations were chosen as markers of 'indisputable typological similarities' with the cultural traditions of Asia Minor on the one hand and the marker of sequential demic expansions from the Konya plain in central Anatolia to floodplains in Thessaly first, and to the Danube and Carpathian Basins later on. It is worth remembering that in the broader Eurasian context, the earliest pottery in Thessaly predates by two centuries the appearance of pottery in western Anatolia, and that there is no significant chronological difference in pottery appearance, whether located on the southern tip of the Balkan Peninsula in Thessaly or in its most northerly margin in the Danube Region (Budja 2003a; 2004).

Iann Hodder (1990.28-30) believes that on the margin of the early Neolithic world in the hunter-gatherer settlement palimpsest at Lepenski Vir in the Danube basin he can read how economic domestication is associated with or is preceded by social and symbolic domestication. As there is no evidence of domesticates available, he puts forward the idea that the trapezoidal houses objectifying arena where indigenous hunter-gatherers neolithicise themselves socially and symbolically. The act of domestication is supposed to have been dramatic. The dead bodies and/or selected bones of ancestors and the antlers of wild stag were brought into the houses and buried within the domus. The same principle he applies to "cultural products", stone sculptures and statutes, which being wild because depict fish-like ancestors and retaining the form of natural boulders. They become domesticated when brought into houses and placed behind hearths. Pottery was not part of the scenario, although the excavator of the site, while 
interpreting the Mesolithic cultural phases at Lepenski Vir, pointed out that monochrome pottery fragments had been found lying on the floor of fifteen Mesolithic trapezoidal buildings. He described the pottery assemblage as comprising simple forms with limited ornamental techniques and motifs. The pots were mainly undecorated, and those that were ornamented comprised impressed ornamentation made by fingertip and fingernail or the edges of freshwater shells and awls (Srejović 1971.8-9). Pottery was contextually associated with burials, stone and other decorated sculptures, altars, and artefacts ornamented with various symbols and attached meanings deposited on the floors of the same buildings. A remarkable symbolic structure was well preserved in the centrally positioned trapezoidal building. A pot adorned with spiral ornaments was deliberately incorporated into a context associated with burials of newborns, and red and black coloured stone sculptures. Special attention should also be drawn at this point to a building where pottery was associated with a deer skull, a stone figurine and two juvenile burials (Garašanin and Radovanović 2001.120, Fig. 4; Borić 1999.52; 2002a.Fig. 7; Budja 2003a. 347-359).

The Lepenski Vir site in general, and trapezoidal buildings in particular, were recently dubbed a "deep time metaphor". Borić (2002b.46-74; see also Chapman 1993.71-121) hypothesises that they represent sacred heirlooms upon which repetitive mnemonic and apotropaic practices were performed. Houses with buried ancestors and animals and "boulders" placed on limestone floors he recognizes as sources of ancestral and apotropaic power and potency, evolving a consciousness of a collective deep time. From this perspective the disarticulated ancestral bones and skulls are attributed first-class apotropaic power and potency. Sculptured boulders are assigned as second-class agencies in anchoring and emitting ancestral powers and potencies.

It is well known, however, that almost all of them are carved, engraved and red and/or black painted with secondary (hydrothermal) pigment that can be distinguished from traces of burning (Srejovic and Babović 1983; Radovanović 1996.140). But it is less known they bear petroglyphs, which we can interpret in accordance with a neuropsychological model of altered consciousness as 'signs of all time' entoptic motifs and their construals (Fig. 16) and theriantropes (Fig. 17). Topographic markers and landscape representations are attached to some others (Fig. 18). They might have been maps and were

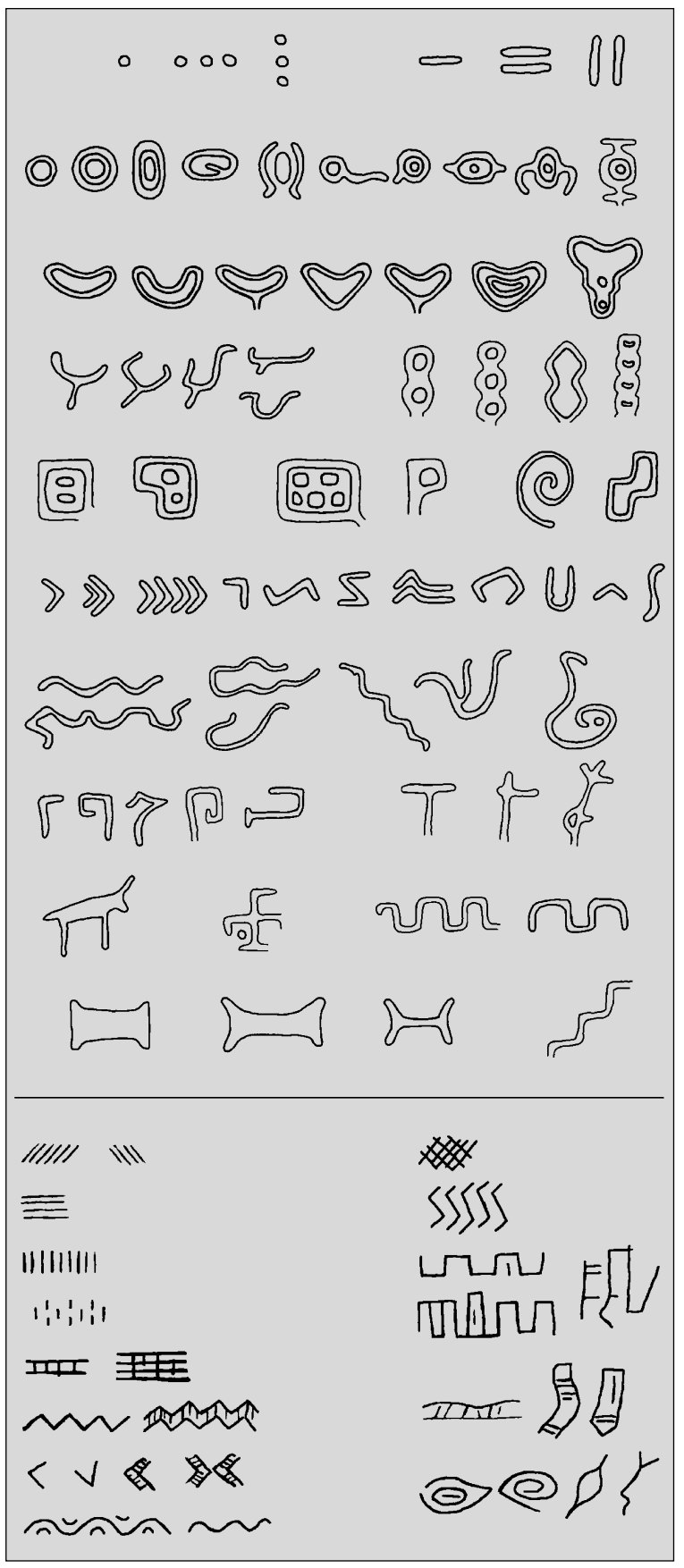

Fig. 19. Lepenski Vir. Engraved and incised imagery attached to stone monuments and stone, bone and antler tools and implements (after Srejović and Babović 1983.Figs. 29 and 34).

perceived as mnemonic devices and as such can be incorporated into Zubrow's and Daly's corpus of prehistoric maps mentioned above. It is worth remembering that similar imagery was also attached to stone, bone and antler tools, and implements (O.c.) (Fig. 19).

It is well known that they were embedded in hunter-gatherer settlement contexts at Lepenski Vir. But it is less known that they have also been found at 


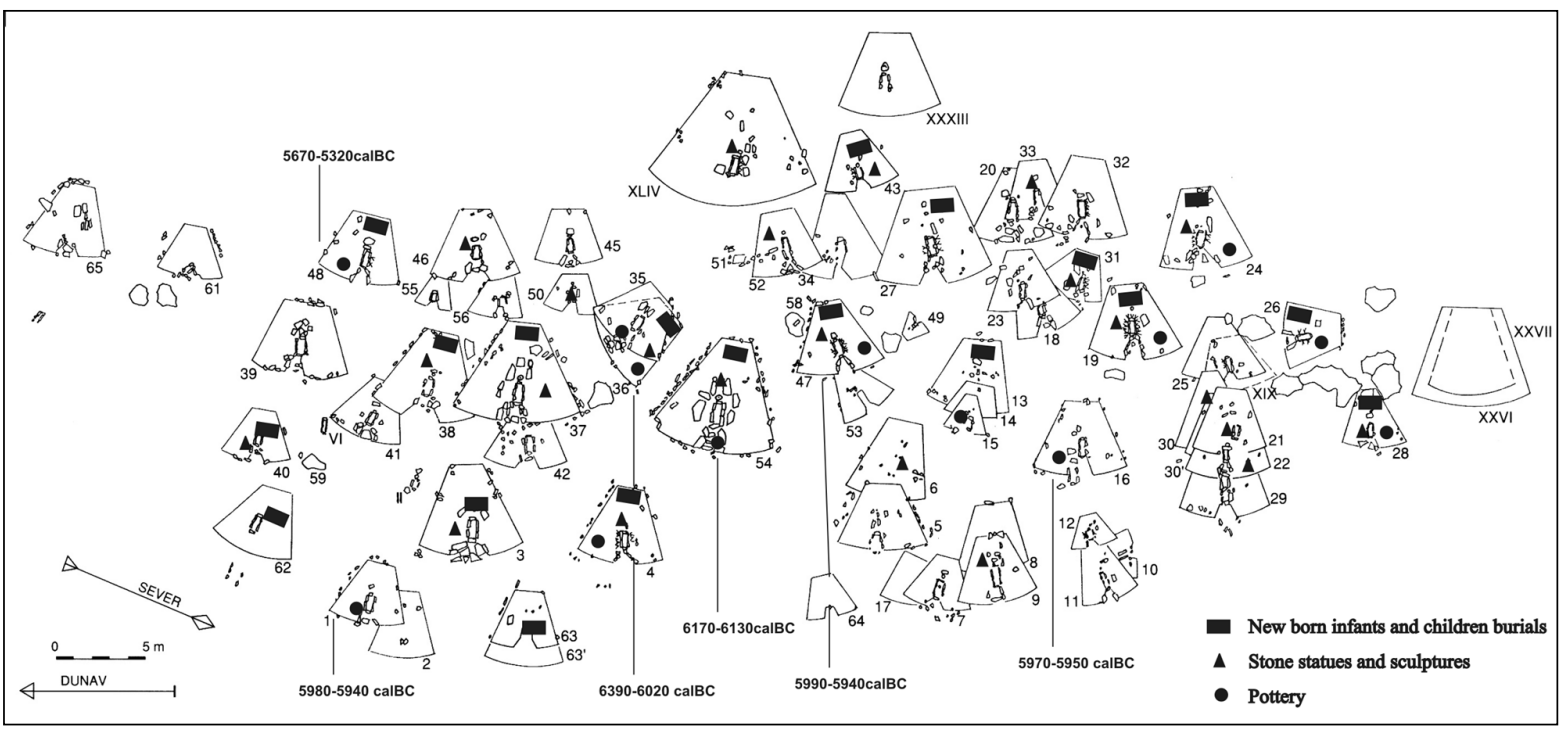

Fig. 20. Lepenski Vir site plan showing centrally positioned trapezoidal building 54, and children burials, stone boulders and pottery distributions (after Babović 1997.Slika 1; Bonsall et al. 2000.Fig. 8; Borić 2002.Fig. 7).

Vlasac, Padina, Hajdučka Vodenica, Cuina Tarcului and Schela Cladovei in the Danube Djerdap gorges (Srejović and Babovic 1983.56-57; Boroneat1990. 479). And it has been overlooked for decades that they were embedded in agricultural settlement contexts at Gura Baciului in Transylvania (Vlassa 1972. 187-191; Lazarovici and Maxim 1995.379).

We may hypothesise that hunter-gatherers and early farmers in the northern Balkans and Carpathians transformed the basic rock art principles in a way they made them portable and incorporated them into settlement and dwelling contexts. It is not that they brought and circulated the monuments within and between the settlements, but fixed them inside the trapezoidal buildings.

The sandstone boulders and blocks were brought from some $10 \mathrm{~km}$ from the upper stream of a tributary of the Danube. Contextual studies show a clear spatial patterning of monuments within the buildings, as a high percentage of monuments are found behind the hearths at the rear of the houses (Srejović1969; Srejović and Babović 1983; cf. Chapman 1993.103) and associated with burials, some of them of new born infants and children (Budja 2003.352, Fig. 3). They were not visible from the outside.

Were they institutionalised to mark the houses of ancestors and places of communal rituals, as is widely suggested? Perhaps, although it seems unlikely that the location of standing monuments in the dark confines of the rear of the buildings was conducive to communal, public and open rituals. It would be con- venient to hypothesise closed, lineal or kinship shamanic rituals in household contexts, like the shamanistic role in Lepenski Vir already suggested. The male remains in grave 69 show he was buried in a seated position, and it is believed he was a shaman, as the trapezoidal disposal of his skeleton is clearly reminiscent of an architectonic canon which was adhered to for a millennium (Srejović 1969.90; Srejović and Babović 1983.44-45).

Freidman and Rowlands presented in seventies (1977.201-276) a model of social dynamics in 'tribal' societies whereby competitive feasting in the context of ritual activities may led to the emergence of dominant groups with special status involving control of rites and mediation between the community and the supernatural but also over the production and circulation of goods outside the local territory.

The question of the meaning of the geometric and iconic features attached to the boulders and tools remains. It would be convenient, again, to ascribe them to mental imagery that became part of a complex system of representation, and to prominent shamans who controlled by the agency of altered states of consciousness supernatural potency and manipulate with prestige and power. We must remember, however, that these symbolic storages were spatially embedded on the extremely strict geographical boundary in Danube Djerdap gorges that must have been respected in deep time as much by hunter-gatherers and nomadic pastoralist as farmers. 


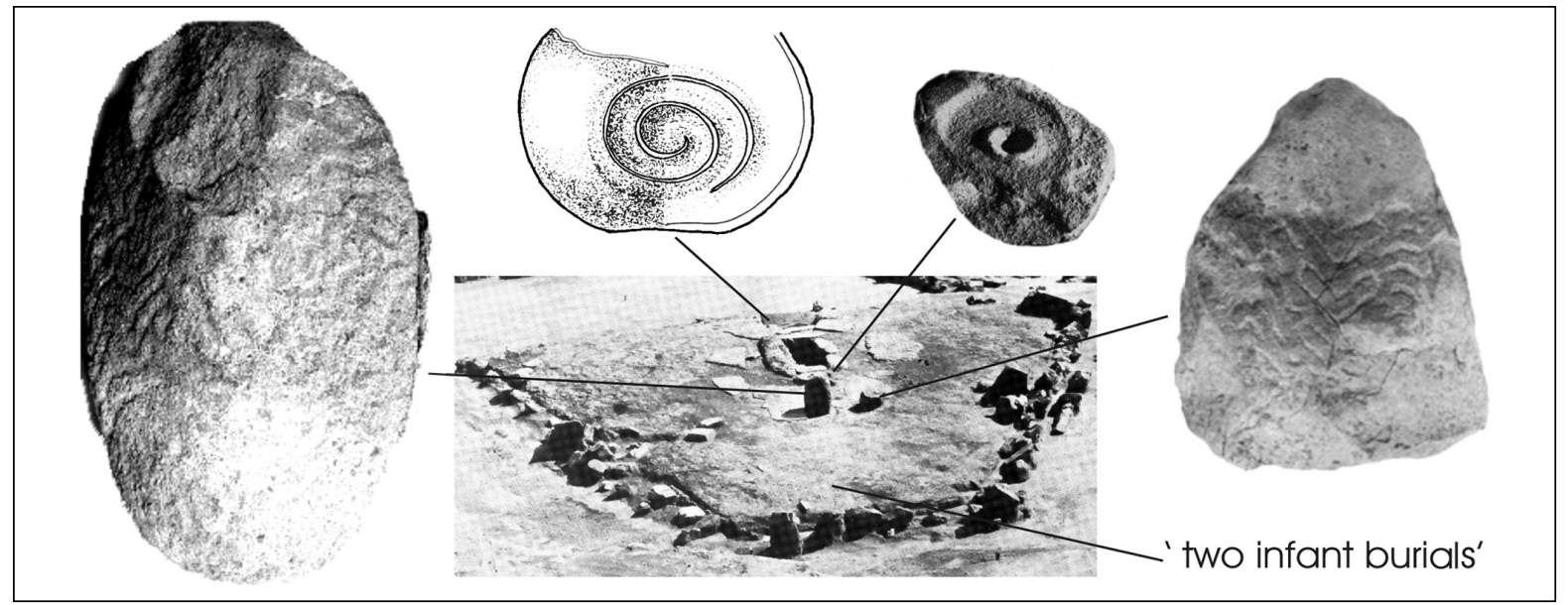

Fig. 21. Lepenski Vir. Symbolic inventory of the building 54 (after Srejović and Babović 1983.18, 9293,167; Garašanin and Radovanović 2001.Figs. 1-3).

Ethnographic evidence of complex shamanic rituals and related depictions show that shamans and their power were clearly recognized in small societies and their internal social dynamics, as well as in external communications and even interactions between foragers and farmers. Thus !Kung (San) Bushman shamans struggle in the spirit world of trance experience against frightening spirits of the dead which during the ritual hover in the darkness beyond the light of the fire. The social relations between Bantu speaking farmers and San foragers are well known. Farmers recognized them as the original inhabitants and custodians of the land, but as the farmers were more dependent on rain, they requested San rain makers to perform rituals, giving them cattle in return. Thus shamans have ideological control over the farmers' economy on the one hand, and a new status as procurers of meat, with the power to distribute it, on the other. If !Kung woman marries into a farming community, in some cases the !Kung families acquire cattle as bridewealth (Lewis-Williams 1991.150-153; Dowson 1994.337-341; 1998b.336339).

The interpretation of the Lepenski Vir iconography is based on the myth that all men were children of the river and descendants of mermen (Srejovic 1972.122; Radovanović 1996a.39-43; 1997.8791; Whittle 1998.138-145). Radovanović describes the river as being of critical and central importance as the direction for the passage upstream of the ancestors and the departure downstream of the dead, and as a metaphor for death and endings on the one hand, and life and return on the other.

The annual returns of anadromous fishes, sturgeon (Acipenser sturio) and Beluga (Acipenser huso) reaching up to 9 metres long and weighing up to 1500 kilograms and living up to 150 years, migrating from the Black Sea and the Mediterranean to the Danube must have been an impressive event, and it is not surprising that fish find their place in the symbolic imagery. But they were not the staple food there and survival did not depend greatly on fishing.

However fish-like forms and theriantropes have been well recorded in external symbolic storages on petroglyphs and stone monuments.

For our approach the important complex symbolic structure at Lepenski Vir is embedded in the centrally positioned trapezoidal buildings mentioned above. It consisted of a hearth positioned in the centre of the building, a ceramic pot placed in front of it, three stone monuments behind it: an altar and two erected boulders bearing petroglyphs, painted red and black, with the mandible of a mature woman deposited within it, and two burials of newborns in the rear of the building. The context is

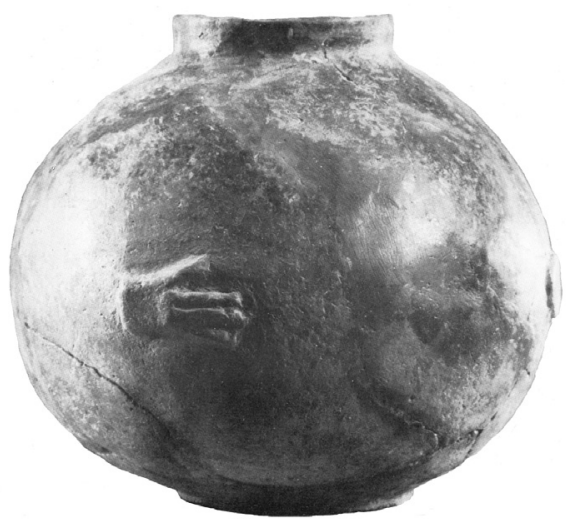

Fig. 22. Lepenski Vir. Human hands modelled on globular ceramic pot (after Srejović 1969.Fig. 90). 

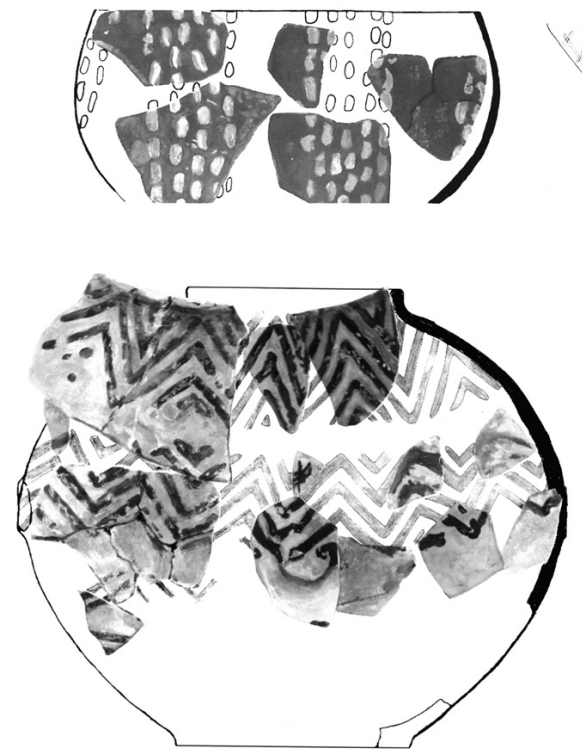

Fig. 23. Gura Baciului and Elešnica. The earliest coloured motifs attached to pottery (after Lazarovici and Maxim 1995.PC I, III, VII; Nikolov and Maslarov 1978.Fig. 2).

radiocarbon dated to $6170-6130 \mathrm{cal} \mathrm{BC}$ at $2 \sigma($ Srejović and Babović 1983; Garašanin and Radovanović 2001.118-120; Borić 2002.1032; Budja 2003a.352-355) (Figs. 20, 21).

We argued recently that pottery was deliberately incorporated into hunter-gatherers' symbolic structures in the Balkans, and we do not need to consider ceramics as exclusively related to farmers. The almost simultaneous interregional distribution of pottery in the Balkans, Ionia and the Adriatic reflects a network of integrative mechanisms that in some regions predate the farming economy and made possible the selective adoption of crops and/or animal husbandry in others (Budja 2001.27-47; 2003a).

It is our belief that pottery in the hunter-gather contexts in Lepenski Vir should not be marginalized to the level of containers and cooking pots, but understood in a complex symbolic scenario as a new medium bearing an old symbol. The vessel was certainly not incorporated into the symbolic structure of the central building by coincidence, and the spiral motif on it was certainly not attached by chance, as it represents one of the basic petroglyph motifs (Fig. 19), which was not applied to any other vessel found there. There must have been ideological reasons
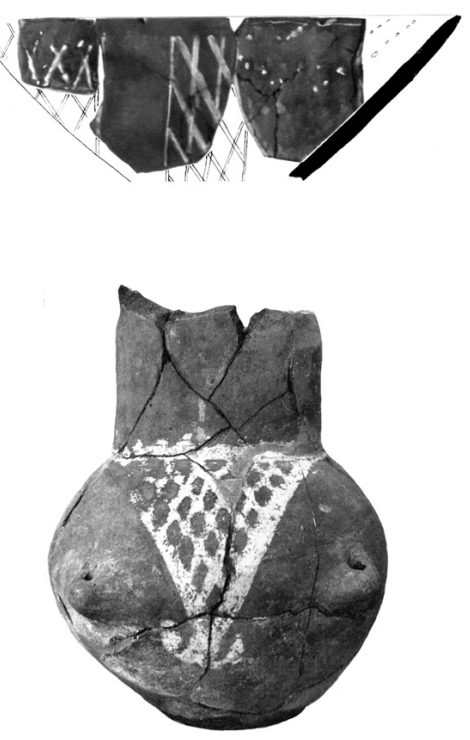

for ceramic vessels not having been coloured, although the technical manipulation of pigments and ornamental techniques was broadly applied to stone monuments. The pottery's ornamentation was limited to finger, nail and awl impressions.

In discussing Lepenski Vir cosmology we should not overlook the particularly narrative symbolism, as shown in a human hands modelled on a large globe-like ceramic pot (Fig. 22). There is again an old symbol on the new medium, giving good reason to believe that the image itself and the act of inscribing it on ceramic vessel are simply parts of a longer chain of operations entailing hunter-gatherers' rituals and beliefs.

When the 'painted pottery' appeared in the Balkans the first coloured motifs attached to the vessels had extremely standardized forms, patterns and colours. They were white and correlate perfectly with the basic list of 'signs of all time', which consists of dots, grids, zigzags and parallel lines (Fig. 23). Red and black correlate with more complex motifs and patterns: triangles, squares, circles, spirals, arcs, crosses and meanders which were adopted later (Schubert 1999; Nikolov 2002).

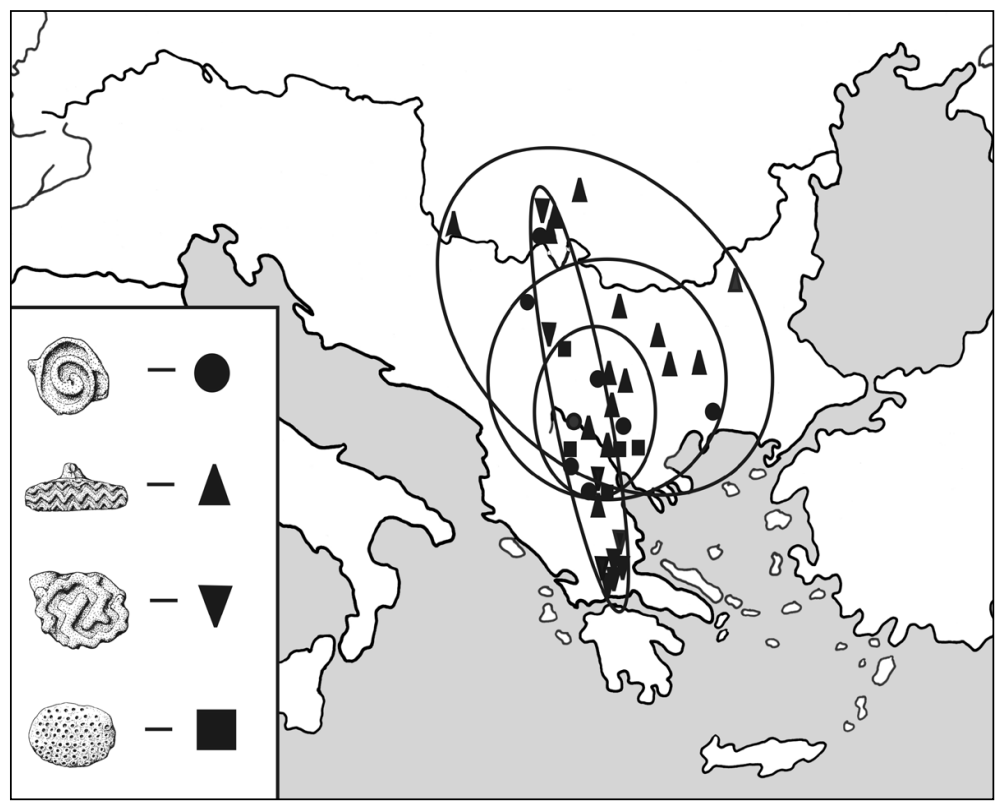

Fig. 24. Regional and interregional spatial distributions of stamp seals (after Budja 2003.Map 2). 
The ceramic and stone stamp seals (pintaderas) mentioned above are even better indicators, as they exhibit a chronological and typological sequence, but have more structured spatial distributions that might indicate local, regional and interregional cultural practices and social networks in the Balkans. While a labyrinthine design was decorated the first series of stamp seals in Thessaly, dots, zigzags and spiral designs were distributed in the other parts of the Balkans and Carpathians (Budja 2003b.115130). (Fig. 24)

So, in summary we again point to the complex assemblage deposited in an agropastoralist settlement context at Gura Baciului in Transylvania that has been overlooked for decades (Vlassa 1972.178190; Lazarovici and Maxim 1995.379-384). The similar principles we met in the hunter-gatherer context at Lepenski Vir are clearly recognizable: burials, fifteen sculpted monumental boulders, some placed on ceramic pedestals and stone plates with attached petroglyphs. While the impressed motifs on the pottery are identical to those from the Danube Djerdap Gorge, all the others are white and rarely red, and restricted to grids, zigzags and parallel lines. Stone and ceramic female figurines, and images and animal statuettes are reappeared finally (Fig. 22, 25). We might interpret bovine-like statuettes, supposedly representing Bos primigenius, as an indicator of economic change, as well as the broadening of the hunter-gather symbolic structure.

\section{CONCLUSIONS}

It would be incorrect not to remind us of Boroneats (1990.479) appreciation that the geometric motifs attached to hunter-gatherer tools and implements are identical to those painted on farmers' pottery, and that the "discovery of clay baking and processing towards the end of the Epi-Palaeolithic" in the Balkans and Carpathians resulted in the replacement of stone monuments with ceramic "idols".

We can assume that external symbolic storage employing technical and symbolic culture was therefore a characteristic of hunter-gatherer as much as of ag-

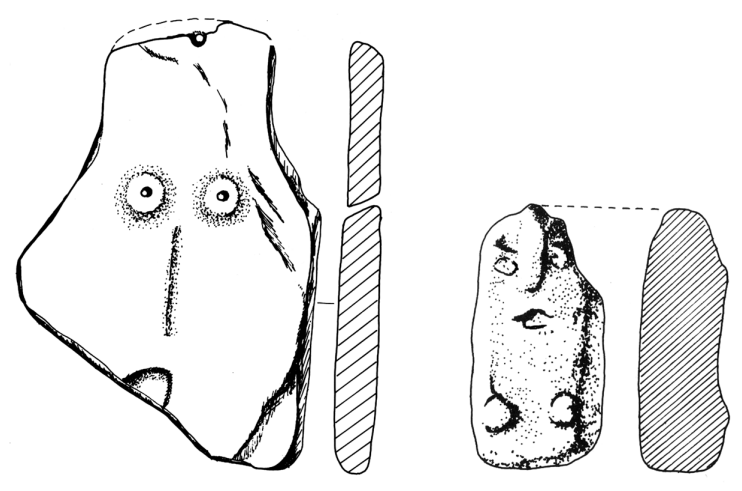

Fig. 25. Gura Baciului, stone plate with attached anthropomorphic image and ceramic female figurine (after Lazarovici and Maxim 1995.Fig. 21, Fig. 22.1)

rarian societies. From our arguments here we should expect that hunter-gather symbolic structures in the Balkans and Carpathians maintained long traditions and that the 'revolution of symbols' in the context of the transition to farming is not a paradigm we have to adopt.

Ceramic technology and the principles of fragmentation and accumulation were certainly not the exclusive domains of farmers. As the entoptics, on the other hand, were certainly not the principle exclusively driven in hunter's and foragers' societies that disappeared in the process of transition to farming. We agree with the critical appreciation that any geometric motif by itself can not be identified as entoptic in origin and therefore indicative of shamanism. Nevertheless, the first coloured motifs attached to vessels are extremely standardized in terms of form, pattern, and colour, correlating with the basic list of 'signs of all time'. The same concept was applied to stamp seals. Additionally, both were integrated in Early Neolithic settlements in the Balkans and the Carpathians where some were associated with collections of prestige objects (Budja 2003.115-130).

Our basic premise is that the hunter-gatherers' symbolic structures and the process of transition to farming were not exclusive and competitive, but rather correlative in maintaining control and power within society and over the frameworks of external interactions and exchange networks. 


\section{REFERENCES}

ABRAMOVA Z. A. 1962. Paleoliticheskoe iskusstvo na territorii SSSR. Moskva \& Leningrad.

ASAAD G. and SHAPIRO B. 1986. Hallucinations: Theoretical and Clinical Overview. American Journal of Psychiatry 143(9): 1088-197.

BARLEY N. 1994. Smashing pots. Feats of clay from Africa. British Museum Press. London.

BORIĆ D. 1999. Places that created time in the Danube Gorges and beyond, c. 9000-5500 BC. In M. Budja (ed.), $\sigma^{\text {th }}$ Neolithic Studies. Documenta Praehistorica XXVI: 41-70.

2002a. The Lepenski Vir conundrum: reinterpretation of the Mesolithic and Neolithic sequences in the Danube Gorges. Antiquity 76(294): 10261039.

2002b. 'Deep time' metaphor. Journal of Social Archaeology 3(1): 46-74.

BORONEATV. 1990. Thoughts on the Chronological Relations between the Epi-Palaeolithic and the Neolithic of the Low Danube. In C. Bonsall (ed.), The Mesolithic in Europe: 475-480.

BOUISSAC P. 2004. Criteria of Symbolicity: Intrinsic and Extrinsic Formal Properties of Artifacts. http:// www.semioticon.com/virtuals/symbolicity/clever. html

BRADLEY R. 2000. An Archaeology of Natural Places. Routledge. London.

BUDJA M. 1996. Neolithisation in the Caput Adriae region: between Herodotus and Cavalli-Sforza. Poročilo o raziskovanju paleolitika neolitika in eneolitika v Sloveniji XXIII: 61-76.

2001. The transition to farming in Southeast Europe: perspectives from pottery, In M. Budja (ed.), $8^{\text {th }}$ Neolithic Studies. Documenta Praehistorica XXVIII: 27-48.

2003a. Symbolic systems in the context of transition to farming in Southeast Europe. Pottery and boundaries. In L. Nikolova (ed.), Early Symbolic Systems for Communication in Southeast Europe. BAR IS 1139: 347-360. 2003b. Seals, contracts and tokens in the Balkans Early Neolithic: where in the puzzle. In M. Budja (ed.), 10th Neolithic Studies. Documenta Praehistorica 30: 115-130.

2004. The Neolithization of the Balkans: where in the puzzle? In M. Zvelebil (ed.), Origins of the LBK, British Archeological Reports. International Series, in press.

CAUVIN J. 2000. The Birth of the Gods and the Origins of Agriculture. Cambridge University Press. Cambridge.

CHAPMAN J. 1993. Social Power in the Iron Gates Mesolithic. In J. Chapman and P. Dolukhanov (eds.), Cultural Transformations and the Interactions in Eastern Europe. Worldwide Archaeology Series: $71-121$.

CHAPMAN J. 2000. Fragmentation in Archaeology. Routledge. London and New York.

CHEN ZHAOFU 1991. Zhongguo Yanhua Faxian Shi. (History of the Discovery of Chinese Rock Art). Shanghai.

CHILDE V. G. 1951. Man Makes Himself. Watts \& Co. London.

COLES J. 2000. Patterns in a Rocky Land: Rock Carvings in South-West upland, Sweden. Exeter.

DEMATTÈ P. 2004. Beyond Shamanism: Landscape and Self-expression in the Petroglyphs of Inner Mongolia and Ningxia (China). Cambridge Archaeological Journal 14(1): 5-23.

DONALD M. 1991. Origins of the Modern Mind: Three Stages in the Evolution of Culture and Cognition. Harvard University Press. Cambridge (MA).

1997. Precis of Origins of the modern mind: Three stages in the evolution of culture and cognition. Behavioural and Brain Sciences 16 (4): 737791.

1998a. Hominid Enculturation and Cognitive Evolution. In C. Renfrew and C. Scarre (eds.), Cognition and Material Culture: the Archaeology of Symbolic Storage: 7-17. McDonald Institute for Archaeological Research, Cambridge. 
1998b. Material Culture and Cognition: Concluding Thoughts, In C. Renfrew and C. Scarre (eds.), Cognition and Material Culture: the Archaeology of Symbolic Storage: 181-187. McDonald Institute for Archaeological Research, Cambridge.

DORNAN L. J. 2004. Beyond Belief: Religious Experience, Ritual, and Cultural Neuro-phenomenology in the Interpretation of Past Religious Systems. Cambridge Archaeological Journal 14(1): 25-36.

DOWSON A. T. 1994. Reading art, writing history: rock art and social change in southern Africa. World Archaeology 25(3): 332-345.

1998a. Rock Art: Handmaiden to Studies of Cognitive Evolution. In C. Renfrew and C. Scarre (eds.), Cognition and Material Culture: the Archaeology of Symbolic Storage: 67-76. McDonald Institute for Archaeological Research, Cambridge.

1998b. Like people in prehistory. World Archaeo$\log y$ 29(3): 333-343.

DOWSON A. T. and PORR M. 2001. Special objects special creatures shamanistic imagery and the Auragnacian art of south west Germany. In N. Price (ed.), The Archaeology of Shamanism: 165-177.

EICHMEIER J. and HÖFER 0. 1974. Endogene Bildmuster. Urban\&Schwarzenburg, München, Berlin, Wien.

ELIADE M. 1972. Shamanism: Archaic Techniques of Ecstasy. Bollingen Foundation (Pantheon Books), New York.

FRIEDMAN J. ROWLANDS J. M. 1977. Notes towards an epigenetic model of the evolution of 'civilisation'. In J. Friedman and M. J. Rowlands (eds.), The Evolution of Social System. Duckworth: 177-276.

FRANCFORT H.P. and HAMAYON R. N., BAHN G. P. (eds.) 2001. The Concept of Shamanism: Uses and Abuses. Bibliotheca Shamanistica 10. Akadémiai Kiadó. Budapest.

GAMBLE C. 1982. Interaction and Alliance in Palaeolithic Society. Man 17(1): 92-207.

1999. The Palaeolithic Societies of Europe. Cambridge World Archaeology. Cambridge University Press. Cambridge.
GARAŠANIN M. and RADOVANOVIĆ I. 2001. A pot in house 54 at Lepenski Vir I. Antiquity 75(287): 118125.

GIMBUTAS M. 1982. The Goddesses and Gods of Old Europe, 6500-3500 BC: Myths and Cult Images. Thames and Hudson. London.

1989. The Language of the Goddess. Harper and Row. San Francisco.

1991. The Civilization of the Goddess. Harper. San Francisco.

GOODISON L. and MORRIS C. 1998. Ancient Goddesses: The Myths and the Evidence. University of Wisconsin Press. Madison.

HELVENTSON P. and BAHN P. 2003. Testing the 'three Stages of Trance' model. Cambridge Archaeological Journal 13(2): 213-224.

HÖCKMANN 0. (1965)1967. Menscliche Darstellungen in der bankeramischen Kultur. Jahrbuch des Römisch-Germanischen zentralmuseums Mainz 12: 1-34.

HODGSON D. 2000. Shamanism, Phosphenes, and Early Art: An Alternative Synthesis. Current Anthropology 41(5): 866-873.

HODDER I. 1990. The Domestication of Europe. Structure and Contingency in Neolithic Societies. Blackwell Publishers. Oxford.

KEALLY T. C., TANIGUCHI Y. and KUZMIN V. Y. 2003. Understanding the Beginnings of Pottery Technology in Japan and Neighboring East Asia. In Y. V. Kuzmin (ed.), The Nature of Transition From the Palaeolithic to the Neolithic in East Asia and the Pacific. The Review of Archaeology 24(2): 3-14.

KLEIN C. F., GUZMÁN E., MANDELL C. E. and STANFIELD-MAZZI M. 2002. The role of shamanism in Mesoamerican art: a reassessment. Current Anthropo$\log y$ 43/3: 383-420.

KLÍMA B. 1989. Figürliche Plastiken aus der paläolithischen Siedlung vaon Pavlov. In D. Kaufmann (ed.), Religion und Kult in ur-und frühgeschichtlicher Zeit: 81-90. Historiker-Gesellschaft der DDR. Berlin.

KOZŁOWSKI J. K. 1992. L'art de la Préhistoire en Europe orientale. CNRS. Paris. 
KUZMIN V. Y. 2002. The earliest centres of pottery origin in the Russian Far East and Siberia: review of chronology for the oldest Neolithic cultures. In M. Budja ( ed.), 9th Neolithic Studies. Documenta Praehistorica XXIX: 37-46.

2003. Introduction: Changing the Paradigm. In Y. V. Kuzmin (ed.), The Nature of Transition From the Palaeolithic to the Neolithic in East Asia and the Pacific. The Review of Archaeology 24(2): 1-3.

KUZMIN V. Y. and ORLOVA L. A. 2000. The Neolithization of Siberia and the Russian Far East: Radiocarbon Evidence. Antiquity 74(284): 356-365.

KUZMIN V. Y. and KEALLY T. C. 2001. Radiocarbon chronology of the earliest Neolithic Sites in East Asia. Radiocarbon 43(2): 1121-1128.

KUZMIN V. Y. and SHEWKOMUD Y. I. 2003. The Palaeolithic-Neolithic Transition in the Russian Far East. In Y. V. Kuzmin (ed.), The Nature of Transition From the Palaeolithic to the Neolithic in East Asia and the Pacific. The Review of Archaeology 24(2): $37-45$.

KUZMIN V. Y. BURR S. G. and JULL J. A. 2003. New AMS 14C Data on the Palaeolithic-neolithic transition in the Amur River Basin, Russian Far East: Late Glacial Coexistence. Current Research in the Pleistocene 20: 39-42.

LAYTON R. 2000. Shamanism, totemism, and rock art: Les chamanes de la préhistoire in the context of rock art research. Cambridge Archaeological Journal 10:169-86.

LAZAROVICI G. and MAXIM Z. 1995. Gura Baciuliu. Biblioteca Musei Napocensis XI. Cluj-Napoca.

LESURE G. R. 2002. The Goddess Diffracted. Current Anthropology 43(4): 587-610.

LEWIS-WILLIAMS D. J. 1991. Wrestling with Analogy: A methodological Dilemma in Upper Palaeolithic Art Research. Proceedings of the Prehistoric Society 57 (1): 149-162.

2002. The Mind in Tomb: Consciousness and the Origins of art. Thames and Hudson. London.

2004. Neuropsychology and Upper Palaeolithic Art: Observations on the Progress of Altered Sta- tes of Consciousness. Cambridge Archaeological Journal 14(1): 107-111.

LEWIS-WILLIAMS D. J. and DOWSON A. T. 1988. The Signs of All Times. Current Anthropology 29(2): 201-244.

1990. On Palaeolithic Art and the Neuropsychological Model. Current Anthropology 31(4): 407408 .

1993. On Vision and Power in the Neolithic: Evidence from the Decorated Monuments. Current Anthropology 34(1): 55-65.

MAINA http://www.vm.kemsu.ru/en/palaeolith/ plastic/maina.html

MARSHACK A. 1991. The female image, a "time-factored" symbol: A study in style and modes of image use in the European Upper Palaeolithic. Proceedings of the Prehistoric Society 57: 17-31.

McDERMOTT L. 1996. Self-Representation in Upper Palaeolithic Female Figurines. Current Anthropo$\log y$ 37(2): 227-275.

MELLAART J. 1967. Çatal Hüyük - A Neolithic Town in Anatolia. Thames and Hudson. London.

MESKELL L. 1995. Goddesses, Gimbutas, and "New Age" archaeology. Antiquity 69(262): 74-86.

MILOJČIĆ V. 1959(1960). Ergebnise der Deustschen Ausgrabungen in Thessalien (1953-1958). Jahrbuch des Römisch-Germanische Zentralmuseums Mainz 6: $1-56$.

1960. Praekeramisches Neolithikum auf der Balkanhalbinsel. Germania 38 (3-4): 320-335.

MITHEN S. 1996. The Prehistory of the Mind. Thames and Hudson. London.

MÜLLER K. E. 1972. Geschichte der antiken Ethnographie und ethnologischen Theoriebildung. Von den anfängen bis auf die byzantinischen historiographen. Teil I. Studien zur Kulturkunde. 29 Band. Wiesbaden.

NIKOLOV V. 2002. Frühneolitische Bemalte Ornamentik. Sofia.

NIKOLOV V. and MASLAROV K. 1987. Drevni selišča kraj Elešnica. Sofija Pres. Sofija. 
OSTER G. 1970. Phosphenes. Scientific American 222(2): 83-87.

PERLÈS C. 2001. The early Neolithic in Greece. The first farming communities in Europe. Cambridge World Archaeology. Cambridge University Press. Cambridge.

2003. An alternate (and old-fashioned) view on the Neolithisation in Greece. In M. Budja (ed.), 10th Neolithic Studies. Documenta Praehistorica 30: 99-114.

PERSON L. J. 2002. Shamanism and the Ancient Mind. A Cognitive approach to Archaeology. AltaMira Press. Walnut Creek(CA).

RADOVANOVIĆ I. 1996. The Iron Gates Mesolithic. International Monographs in Prehistory. Archaeological Series 11. Ann Arbor. Michigan.

1997. The Lepenski Vir culture: a contribution to interpretation of its ideological aspects. In M. Lazić (ed.), Uzdarje Dragoslavu Srejović: 87-93. Centre for Archaeological Research, The University Belgrade.

RENFREW C. 1987. Archaeology and Language. The Puzzle of Indo-European Origins. Penguin Books. London.

1998. Mind and Matter: Cognitive Archaeology and External Symbolic Storage. In C. Renfrew and C. Scarre (eds.), Cognition and Material Culture: the Archaeology of Symbolic Storage: 1-6. McDonald Institute for Archaeological Research, Cambridge.

RICHARDS W. 1971. The Fortification Illusions of Migraines. Scientific American 224(5): 88-96.

ROBB E. J. 1998. The Archaeology of Symbols. $A n$ nual Review of Anthropology 27: 329-346.

SCHLESIER H. K. 2001. More on the "Venus" Figurines. Current Anthropology 42(1): 410-412.

SCHUBERT H. 1999. Die bemalte Keramik des Frühneolithikums in Südosteuropa, Italien und Westanatolien. Internationale Archäologie 74.

SHERRATT A. 1991. Sacred and profane substances: the ritual uses of narcotics in later Neolithic Europe. In P. Garwood, D. Jennings, R. Skeates and J. Toms, (eds.), Sacred and profane: proceedings of a conference on archaeology, ritual and religion: 5064. Oxford University Committee for Archaeology, Oxford.

SOFFER 0. VANDIVER P. KLIMA B., and SVOBODA J. 1993. The Pyrotechnology of Perfomance Art: Moravian Venuse and Wolverines. In H. Knecht, A. PikeTay, R. White (eds.), Before Lascaux: 259-275. CRC Pres. Boca Raton.

SOFFER 0., ADOVASIO M. J. and HYLAND C. D. 2000. The "Venus" Figurines. Current Anthropology 41 (4): 511-537.

SOFFER 0. and ADOVASIO M. J. 2004. Textiles and Upper Palaeolithic Lives. A Focus on the Perishable and the Invisible. In A. Svoboda and L. Sedláčková (eds.), The Gravettian along the Danube. Proceedings of the Mikulov Conference, 20.-21. November 2002 Brno. Dolní Věstonice Studies 11: 270282.

SREJOVIĆ D. 1969. Lepenski Vir. Nova praistorijska kultura u Podunavlju. Beograd

1971. Die Lepenski Vir - Kultur und der Beginn der Jungsteinzeit an der mittleren Donau. In Die Anfänge des Neolithikums vom Orient bis Nord Europa. Teil II. Östliches Mitteleuropa. Fundamenta. Reihe A. Band 3:1-39.

1972. Lepenski Vir. London: Thames and Hudson.

SREJOVIĆ D. and BABOVIĆ L. 1983. Umetnost Lepenskog Vira. Beograd.

TALALAY E. T. 1993. Deities, Dolls, and Devices. Neolithic Figurines from Franchthi Cave, Geece. In T. W. Jacobsen (ed.), Excavation at Franchthi Cave, Greece Fasc. 9. Indiana University Press, Indianapolis.

TRIGGER B. 1980. Gordon Childe: Revolutions in Archaeology. Thames and Hudson. London.

TURCONI C. 1998. La mappa di Bedolina nel quadro dell'arte rupestre della Valcamonica. Notizie Archeologiche Bergomensi 5: 85-113.

UCKO P. J. 1968. Anthropomorphic Figurines of Predynastic Egypt and Neolithic Crete with Comparative Material from the Prehistoric Near East and Mainland Greece. Royal Anthropological Institute Occasional Papers 24. Andrew Szmidla. London. 
VANDIVER B. P., SOFFER O., KLIMA B., SVOBODA J. 1989. The Origin of Ceramic Technology at Dolni Věstonice, Czechoslovakia. Science 246(4933): 1002-1008.

VASIL'EV S. A. 1985. Une statuette d'argile paléolithique de Sibérie du Sud. L'Anthropologie 89/2: 193-196.

1996. Pozdny paleolit Verkhnego Eniseya. Petersburg Oriental Studies. St Petersburg.

VASIL'EV A. S., KUZMIN V. Y., ORLOVA A. L., DEMENTIEV N. Y. 2002. Radiocarbon-based chronology of the Paleolithic in Siberia and its relevance to the peopling of the New World. Radiocarbon 44(2): 503-530.

VERPOORTE A. 2001. Places of Art, traces of Fire. Archaeological Studies Leiden University 8/ Dolní Věstonice Studies 6. Leiden, Brno.

VLASSA N. 1972. Eine frühneolitische Kultur mit bemalter Keramik der Vor-Starčevo-KörösZeit in ClujGura Baciului, Siebenbürgen. Praehistorische Zeitschrift 47: 174-197.

WHITTLE A. 1998. Fish, faces and fingers: presences and symbolic identities in the Mesolithic -Neolithic transition in the Carpathian basin. Documenta Praehistorica XXV: 133-150.

WINN M. M. S. 1995. Heaven, Heroes and Happiness. University Press of America. Lanham.

XU CHENG and WEI ZHONG 1993. Helan Mountain Petroglyphs in Ningxia Hui Automous Region, China. Cultural Relics Publishing House. Beijing.

ZHANG CHI 2002. The discovery of early pottery in China. In M. Budja (ed.), 9th Neolithic Studies. Documenta Praehistorica XXIX: 29-35.

ZHAO CHAOHONG and WU XIAOHONG 2000. The Dating of Chinese Early Pottery and a Discussion of Some Related Problems. In M. Budja (ed.), 7th Neolithic Studies. Documenta Praehistorica XXYII: 233-239.

ZUBROW B. W. E. and DALY T. P. 1998. Symbolic Behaviour: the Origin of Spatial Perspective. In C. Renfrew and C. Scarre (eds.), Cognition and Material Culture: the Archaeology of Symbolic Storage: 157174. McDonald Institute for Archaeological Research. Cambridge. 